Prepared for USDA Forest Service, San Dimas Technology \& Development Center, San Dimas, CA 91773; Interagency Agreement No. 09-IA-11138150-041

\title{
Aquatic Organism Passage at Road-Stream Crossings- Synthesis and Guidelines for Effectiveness Monitoring
}

Open-File Report 2012-1090 



\section{Aquatic Organism Passage at Road-Stream Crossings- Synthesis and Guidelines for Effectiveness Monitoring}

Edited by Robert L. Hoffman and Jason B. Dunham, U.S. Geological Survey, and

Bruce P. Hansen, U.S. Forest Service

Prepared for USDA Forest Service, San Dimas Technology \& Development Center, San Dimas, CA 91773; Interagency Agreement No. 09-IA-11138150-041

Open-File Report 2012-1090

U.S. Department of the Interior

U.S. Geological Survey 


\section{U.S. Department of the Interior \\ KEN SALAZAR, Secretary}

\section{U.S. Geological Survey \\ Marcia K. McNutt, Director}

U.S. Geological Survey, Reston, Virginia: 2012

For more information on the USGS-the Federal source for science about the Earth, its natural and living resources, natural hazards, and the environment-visit http://www.usgs.gov or call 1-888-ASK-USGS

For an overview of USGS information products, including maps, imagery, and publications, visit $h$ ttp://www.usgs.gov/pubprod

To order this and other USGS information products, visit http://store.usgs.gov

Suggested citation:

Hoffman, R.L., Dunham, J.B., and Hansen, B.P., eds., 2012, Aquatic organism passage at road-stream crossingsSynthesis and guidelines for effectiveness monitoring: U.S. Geological Survey Open-File Report 2012-1090, 64 p.

Any use of trade, product, or firm names is for descriptive purposes only and does not imply endorsement by the U.S. Government.

Although this report is in the public domain, permission must be secured from the individual copyright owners to reproduce any copyrighted material contained within this report 


\section{Contents}

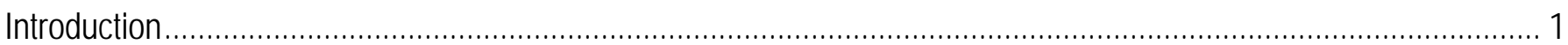

U.S. Forest Service Practices and Aquatic Organism Passage: Historical Context................................................. 3

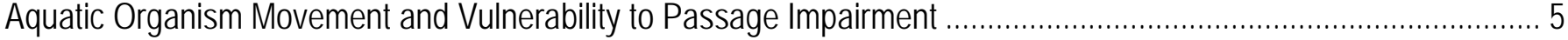

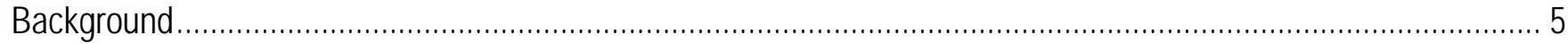

General Model of Aquatic Organism Movement and Passage Impairment Impacts ......................................... 8

Assessment of the Relative Vulnerability of Taxa Groups to Passage Impairment..........................................11

Four Methods for Assessing Aquatic Organism Passage and Restoration Effectiveness .....................................13

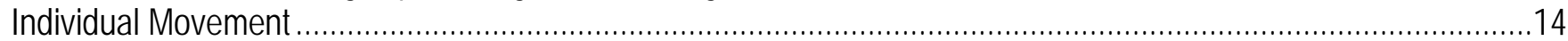

Movement Study Example: Mark-Recapture with Electrofishing and Trapping ...............................................16

Movement Study Example: Mark-Recapture and Passive Integrated Transponder (PIT) Tags. .........................17

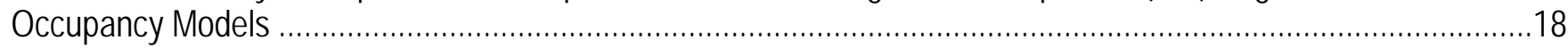

Implementation

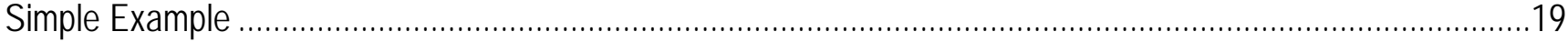

Several Things to Consider About Using an Occupancy Approach........................................................21

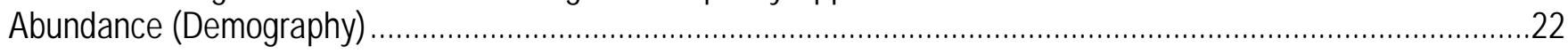

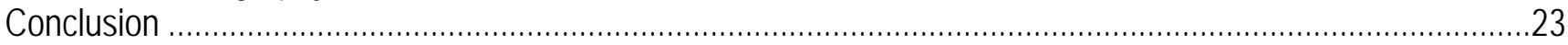

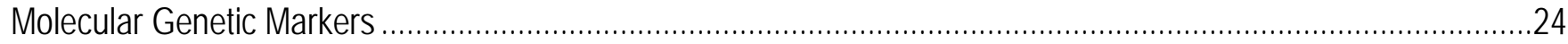

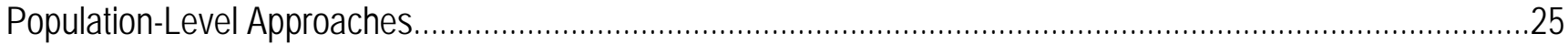

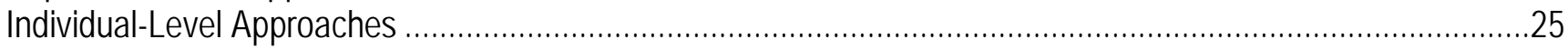

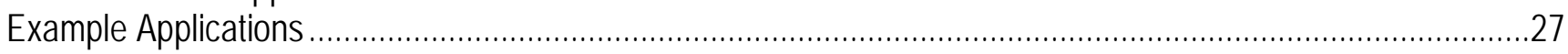

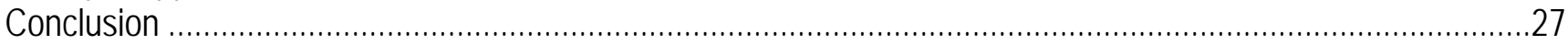

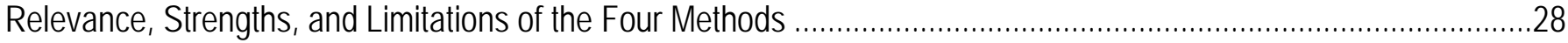

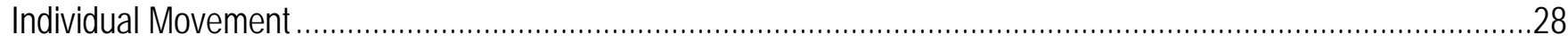

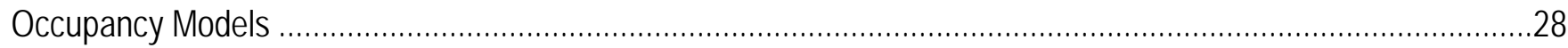

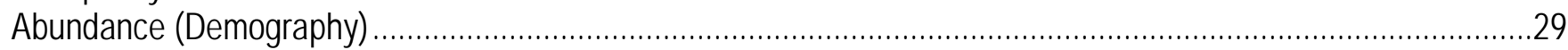

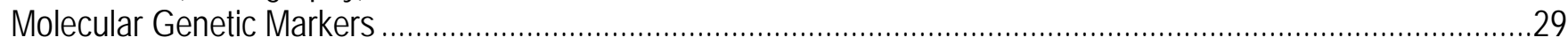

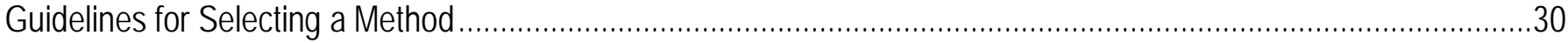

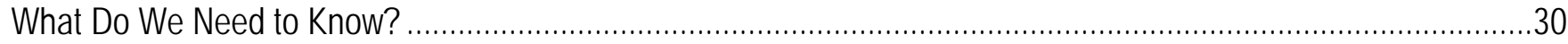

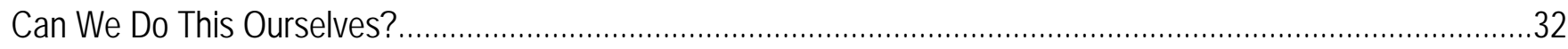

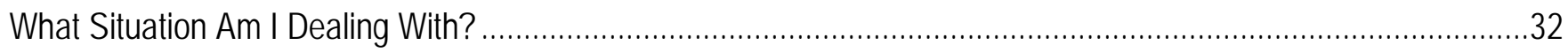

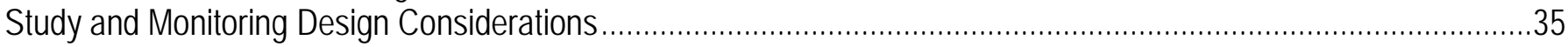

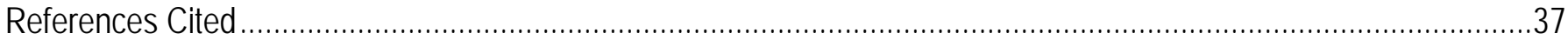

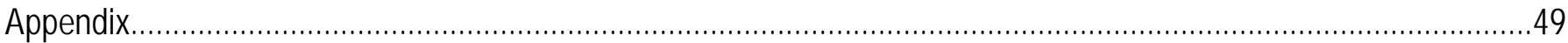

General Movement Characteristics and Impact Summaries .....................................................................49

Fish: General movement patterns of stream fish as expressed by 21 species $(1$ of 5$)$.....................................52

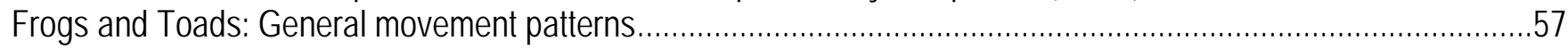

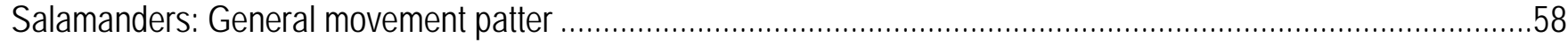

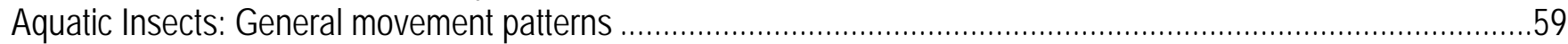

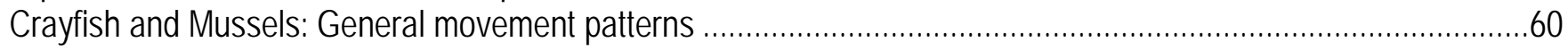

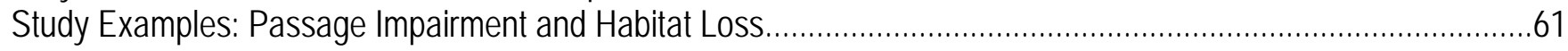

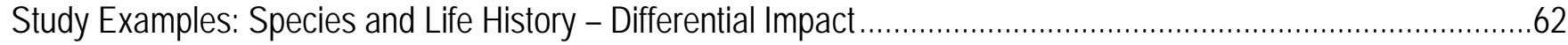

Study Examples: Potential Positive Effects of Restricted Upstream Passage ...................................................63

Invited Attendees at the Aquatic Organism Passage Workshop: Guidelines for an Effectiveness Monitoring

Protocol, Held March 16-18, 2010, Portland, Oregon.........................................................................64 


\section{Figures}

Figure 1. General model of potential impacts to aquatic organism populations above culverts with passage

impairment.

\section{Text Boxes}

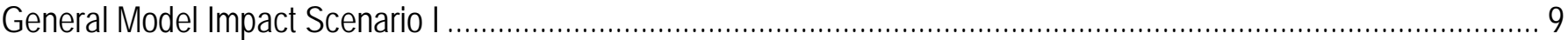

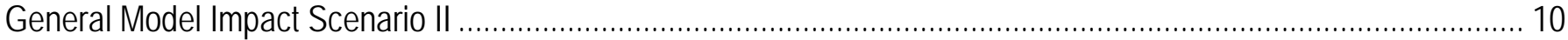

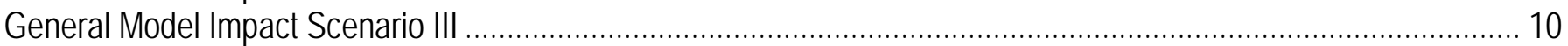

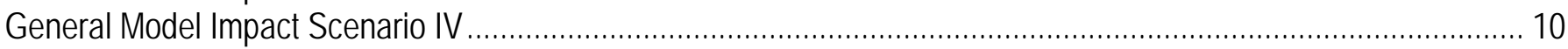

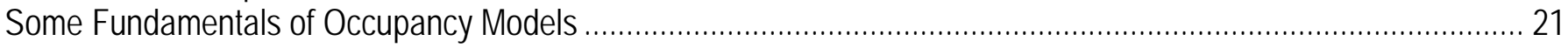

Relatedness reconstruction to assess movement over barrier restoration sites. ................................................... 26

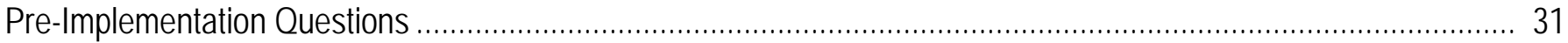

\section{Tables}

Table 1. Summary of generalized movement characteristics of aquatic organisms that inhabit rivers and streams. .... 6

Table 2. General modes of aquatic organism movement categorized by taxonomic group and life stag. ................. 7

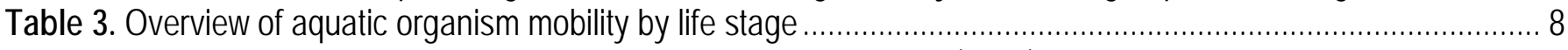

Table 4. Details of the basic design elements of the Burford and others (2009) experiment................................. 16

Table 5. Classification of feasible alternative methods for monitoring biotic responses to the presence of road-stream crossing structures in different scenarios representing variability in species presence and abundance

Table 6. Summary of the utility of each method relative to three basic considerations: (1) the number of road-stream crossing structures of interest; (2) presence of the species of interest relative to the crossing(s); and (3) general focus of the method. 


\section{Conversion Factors}

\begin{tabular}{lcl}
\hline \multicolumn{1}{c}{ Multiply } & By & \multicolumn{1}{c}{ To obtain } \\
\hline centimeter $(\mathrm{cm})$ & 0.3937 & inch (in.) \\
millimeter $(\mathrm{mm})$ & 0.03937 & inch (in.) \\
meter (m) & 3.281 & foot (ft) \\
kilometer $(\mathrm{km})$ & 0.6214 & mile (mi) \\
\hline & Area & \\
\hline square meter $\left(\mathrm{m}^{2}\right)$ & 0.0002471 & acre \\
hectare (ha) & 2.471 & acre \\
square kilometer $\left(\mathrm{km}^{2}\right)$ & 247.1 & acre \\
square centimeter $\left(\mathrm{cm}^{2}\right)$ & 0.001076 & square foot $\left(\mathrm{ft}^{2}\right)$ \\
square meter $\left(\mathrm{m}^{2}\right)$ & 10.76 & square foot $\left(\mathrm{ft}^{2}\right)$ \\
square centimeter $\left(\mathrm{cm}^{2}\right)$ & 0.1550 & square inch $\left(\mathrm{ft}^{2}\right)$ \\
hectare (ha) & 0.003861 & square mile $\left(\mathrm{mi}^{2}\right)$ \\
square kilometer $\left(\mathrm{km}^{2}\right)$ & 0.3861 & square mile $\left(\mathrm{mi}^{2}\right)$ \\
\hline & Mass & \\
\hline gram (g) & 0.03527 & ounce, avoirdupois (oz) \\
kilogram (kg) & 2.205 & pound avoirdupois $(\mathrm{lb})$ \\
\hline
\end{tabular}

Temperature in degrees Celsius $\left({ }^{\circ} \mathrm{C}\right)$ may be converted to degrees Fahrenheit $\left({ }^{\circ} \mathrm{F}\right)$ as follows: ${ }^{\circ} \mathrm{F}=\left(1.8 \mathrm{x}^{\circ} \mathrm{C}\right)+32$.

Temperature in degrees Fahrenheit $\left({ }^{\circ} \mathrm{F}\right)$ may be converted to degrees Celsius $\left({ }^{\circ} \mathrm{C}\right)$ as follows: ${ }^{\circ} \mathrm{C}=\left({ }^{\circ} \mathrm{F}-32\right) / 1.8$. 
This page left intentionally blank 


\title{
Aquatic Organism Passage at Road-Stream Crossings-Synthesis and Guidelines for Effectiveness Monitoring
}

\author{
By Robert L. Hoffman and Jason B. Dunham, U.S. Geological Survey, and Bruce P. Hansen, \\ U.S. Forest Service, editors
}

\section{Introduction}

Restoration and maintenance of passage for aquatic organisms at road-stream crossings represents a major management priority, involving an investment of hundreds of millions of dollars (for example, U.S. Government Accounting Office, 2001). In recent years, passage at hundreds of crossings has been restored, primarily by replacing barrier road culverts with bridges or stream simulation culverts designed to pass all species and all life stages of aquatic life and simulate natural hydro-geomorphic processes (U.S. Forest Service, 2008). The current situation has motivated two general questions:

1. Are current design standards for stream simulation culverts adequately re-establishing passage for aquatic biota? and

2. How do we monitor and evaluate effectiveness of passage restoration?

To address the latter question, a national workshop was held in March 2010, in Portland, Oregon. The workshop included experts on aquatic organism passage from across the nation (see table of participants, APPENDIX) who addressed four classes of methods for monitoring effectiveness of aquatic organism passage-individual movement, occupancy, demography, and genetics.

This report has been written, in part, for field biologists who will be undertaking and evaluating the effectiveness of aquatic organism passage restoration projects at road-stream crossings. The report outlines basic methods for evaluating road-stream crossing passage impairment and restoration and discusses under what circumstances and conditions each method will be useful; what questions each method can potentially answer; how to design and implement an evaluation study; and points out the fundamental reality that most evaluation projects will require special funding and partnerships among researchers and resource managers. The report is organized into the following sections, which can be read independently:

1. Historical context: In this section, we provide a brief history of events leading up to the present situation involving aquatic organism passage as a useful context for the issues covered herein.

2. Importance of connectivity for aquatic organisms: In this section, we provide background information regarding the movement characteristics of aquatic organisms and their vulnerability to passage impairment, and the importance of connectivity for a broad diversity of aquatic vertebrates and invertebrates. This section should be useful for practitioners in selecting what species to monitor in relation to aquatic organism passage. 
3. Methods for evaluating aquatic organism passage: In this section, we present a range of perspectives on alternatives for assessing and monitoring aquatic organism passage impairment and the effectiveness of passage restoration actions, including the following methods: Individual Movement, Occupancy Models, Abundance (Demography), and Molecular Genetic Markers.

4. Relevance, strengths, and limitations of the four methods: In this section, we discuss the utility of each of the methods as a tool for assessing and quantifying passage impairment and restoration effectiveness.

5. Guidelines for selecting a method: In this section, we review some fundamental criteria and guidelines to consider when selecting a method for monitoring in the context of answering three important questions that should be addressed when developing a plan for evaluating aquatic organism passage.

6. Study and monitoring design considerations: In this section, we discuss four key design elements that need to be considered when developing a monitoring design for assessing passage impairment and restoration.

The basic objectives of the report are to:

1. Review the movement characteristics of five groups of aquatic organisms that inhabit streams and to assess their general vulnerability to passage impairment at road-stream crossings;

2. Review four methods for monitoring aquatic organism passage impairment and the effectiveness of actions to restore passage at road-stream crossing structures;

3. Assess the relevance, strengths, and limitations of each method as a monitoring tool;

4. Identify and discuss guidelines that will be useful for selecting a monitoring method; and

5. Discuss what we have identified as the four key elements that need to be considered when developing a monitoring design for assessing passage impairment and restoration at road-stream crossings.

This report does not attempt to provide specific or detailed monitoring protocols or a detailed discussion of analytical and statistical methodologies. We think that this is not possible or appropriate, given the many situations that will be encountered in the field. However, many specific examples and scenarios are highlighted in this report, as well as numerous references that provide such details. We also think that it is more important to compare and contrast the diverse range of options for monitoring that are available to managers, concluding with straightforward guidelines for selecting an approach. Guidelines offered here are centered on the questions to be addressed, as opposed to providing detailed step-by-step instructions. This is in keeping with recent reviews that stress the importance of refining questions to be answered and designing monitoring programs that help us better understand how we are influencing specific biological processes, as opposed to simply treating monitoring as "surveillance" (Nichols and Williams, 2006). 


\section{U.S. Forest Service Practices and Aquatic Organism Passage: Historical Context}

Federal funding for the construction of roads in the national forests of the United States began toward the end of the third decade of the 1900s (Steen, 2004, p. 283-284). By 1928, the U.S. Forest Service (USFS) had developed a plan to construct a system of roads through what was then 26 million acres of forests in Oregon and Washington as a way of providing reasonable access for fighting fires and fire suppression (Buck, 1936). During the 1930s, the Civilian Conservation Corps (1933-42) was responsible for building roads throughout the national forest system (for example: Southern Appalachians [Mastran and Lowerre, 1983, p 78]; southwestern region [Baker and others, 1988, p. 54]; eastern region [Conrad, 1997, p. 102]), in an enhanced effort to provide access to the forests for timber harvesting, fire suppression, and recreation. This period of road building activity was followed in 1950, at the outbreak of the Korean War, by an additional period of intensified road building to again increase access for logging and revenue from federal timber sales, and to enhance "good management” of natural resources (Steen, 2004, p. 283-284). A fourth period of accelerated road building in the national forest system occurred in the 1980s (Penna, 1999, p. 57).

Culverts were installed at many of the road-stream crossings that were common features of this relatively extensive system of forest roads. Because culverts are artificial structures, their installation generally changes the inherent nature of the channel at a road-stream crossing (U.S. Forest Service, 2008). Aquatic organism passage through them can be restricted or completely obstructed due to improper culvert design and placement or eventual culvert failure caused by naturally occurring events such as flooding, sedimentation, or debris flows. The potential impairment to fish passage through poorly designed and placed culverts was recognized early on by McKinley and Webb (1956) and Shoemaker (1956), who reported that the successful upstream passage of migratory fish through culverts was a persistent critical issue, and proposed corrections to culvert design that they determined would create "optimum conditions," such as decreased streamflow and increased water depth within a culvert, that would facilitate fish passage.

The passage of aquatic organisms, especially migratory fish, through culverts has continued to be an important issue of concern for Federal and State agency resource managers responsible for maintaining the ecological health, integrity, and connectivity of rivers and streams. Three bibliographies (Anderson and Bryant, 1980; Copstead and others, 1998; Moore and others, 1999) have collectively compiled 506 references completed between 1943 and 1999 that deal with multiple aspects of road-stream crossing structures. Of these, 388 focus on overall culvert design, maintenance, installation, failure, hydraulics, and hydrology; 118 are concerned with culvert design for fish passage, risk analysis, and fish swimming ability. Some early examples of references from the latter group include: (1) results of the investigation of 40 
highway structures to identify characteristics of the structures that do not hinder anadromous fish passage (Kay and Lewis, 1970); (2) field review of 61 culverts installed from 1916 to 1970 to evaluate condition and to determine if changes to culvert design and placement over time were effective in preserving upstream fish habitat (McClellan, 1971); (3) guidelines for correct culvert installation (Gebhards and Fisher, 1972) and for identifying and correcting fish passage problems (Evans and Johnson, 1972); (4) an article focused on impacts to stream hydrology and fish biology due to improper culvert design (Dryden and Jessop, 1974); and (5) a literature review and interview of experts to identify fish passage problems and determine if there might be culvert engineering solutions to the problem of restricted passage (Lowman, 1974).

In the last 20 years, several documents have been published that have synthesized and built upon past research, providing enhanced insight and guidance as to how we can and should move forward toward resolving issues related to impaired organism passage at road-stream crossings. The Northwest Forest Plan, an integrated and comprehensive design for the management of forest ecosystems in western Oregon, Washington, and northern California, was adopted in 1994. The plan included an Aquatic Conservation Strategy (U.S. Forest Service and Bureau of Land Management, 1994; Reeves and others, 2006) with objectives that included maintaining and restoring intra- and inter-watershed connectivity, unobstructed access to critical life-sustaining habitat, and providing and maintaining fish passage at all road-stream crossings. Five years later, the USFS published a document that described the process to be followed for the inventory of national forest roads and assessment of their benefits and risks relative to ecological, social, and economic factors (U.S. Forest Service, 1999). The assessment process highlighted the importance of integrating aspects of aquatic ecosystems, such as fisheries biology and stream hydrology, as part of the analysis. In 2001, the National Marine Fisheries Service, in response to the listing of anadromous salmon species in California as threatened and endangered, published guidelines for the design of road-stream crossing structures that would facilitate the upstream and downstream passage of migrating salmon (National Marine Fisheries Service, 2001). The guidelines were based on culvert design criteria published by multiple Federal and State agencies and organizations. Finally, also in 2001, the U.S. General Accounting Office released a document that summarized the challenges facing the USFS and BLM in restoring fish passage through culverts on public lands in Oregon and Washington (U.S. General Accounting Office, 2001). The report included a cost estimate (\$375 million) to replace all culverts thought to be barriers to fish passage (estimated to be approximately 5,500), and concluded that because of the cost and time involved (up to several decades), restoration efforts needed to be systematic and prioritized based on clearly defined criteria that assessed the level of passage impairment at road-stream crossings; and that restoration efforts needed to be monitored to help identify the methods most successful in restoring fish passage. 
In response to these concerns and recommendations, the USFS developed an inventory and assessment procedure "designed to be a nationally applicable, consistent method of identifying crossings that impede passage of aquatic organisms in or along streams" (Clarkin and others, 2005, p. 2). The procedure formalized and systematized the assessment of the status of road-stream crossing structures, a necessary first step in effectively dealing with the many known and emerging issues associated with these structures, and reinforced the notion that passage assessments needed to be species as well as life-stage specific (that is, apply to all aquatic organisms), and should provide an approximate cost for passage restoration (including redesign or replacement). The inventory and assessment procedure also recognized that efforts to assure aquatic organism passage at road-stream crossings should be effective for the entire stream ecosystem (that is, include all biota and physical processes, such as the downstream transport of floodwaters, sediment, and woody debris), rather than primarily focused on specific species and life stages. The concept that passage restoration needed to be ecosystem-based was further elaborated in 2008 in another USFS National Transportation and Development program publication (U.S. Forest Service, 2008) that proposed the use of stream simulation methods and design standards for restoring organism passage and connectivity for the overall purpose of maintaining animal populations, communities, and habitats. This document provided detailed guidance on how to assess, design, and construct stream simulation structures to fulfill the goal of restoring the connection between upstream and downstream sections of a stream, and for reestablishing the integrity of the stream ecosystem.

\section{Aquatic Organism Movement and Vulnerability to Passage Impairment}

\section{Background}

The River Continuum Concept elucidated by Vannote and others (1980) describes a river system as "a continuous gradient of physical conditions” to which biotic populations and communities, and ecosystem processes respond. In this context, the physical and hydrological characteristics of a river act as an organizing template (Southwood, 1977) upon which patterns of biotic organization are expressed from the headwater reaches of the system to its downstream segments (Frissell and others, 1986). These patterns are an expression of the diverse resource patches and habitats that comprise and structure the river system at the landscape-level (Frissell and others, 1986; Taylor and others, 1993; Rosenberg and others, 1997; Fausch and others, 2002). The connectivity of these patches and habitats is important because they act as biological corridors through which animals move to acquire the resources they need for the fulfillment of their life cycles and expression of their life histories (Dunning and others, 1992). Disturbance of this connectivity can lead to fragmentation and loss of habitat, as well as isolation of populations and, potentially, their eventual extinction (Taylor and others, 1993; Rosenberg and others, 1997; Fausch and others, 2002). This is why it is important, in part, to maintain the integrity of the physical-hydrological processes of a river system and the interconnectedness of its resource patches and habitats. 
Organisms that inhabit river systems have a diverse repertoire of movement characteristics (table 1) and modes of movement (table 2) that vary within and among taxonomic groups and by life stage (table 3). Their movements can be limited, typically stationary but capable of making relatively localized, short-distance movements; or active, associated with activities, such as resource acquisition, territory defense, predator avoidance, and reproduction. The movements of riverine organisms also can be passive, occurring involuntarily during periods of high-flow or triggered by stochastic processes, such as flooding or streambank failure. Movements also can be facultative, such as when individuals move among channel units, within a home range, or during exploratory excursions into contiguous or disjunct resource patches or habitats; or obligate like the fixed patterns of migratory behavior in Pacific salmon (Rieman and Dunham, 2000). Movements can further be categorized according to the general purpose for moving (for example, foraging-feeding, dispersal, reproduction), as well as relative to the timing of movement (for example, diel, seasonal, multi-year) and the distance moved (spatial scale). With this diversity of movement, it is no wonder that the various groups of taxa that inhabit river systems are differentially affected by naturally occurring and human-caused disturbances and changes to the structure and integrity of riverine environments including the potential restriction or elimination of upstream movement at road-stream crossings. Particularly illustrative of this variability are the summaries and pattern tables (APPENDIX) we have developed that describe and list the general movement characteristics and patterns of various species of fish, amphibians, aquatic insects, crayfish, and mussels. These summaries and tables describe the range of movement types and patterns within each taxa group and some possible responses (positive and negative) of each group to passage impairment and barriers to upstream movement.

Table 1. Summary of generalized movement characteristics of aquatic organisms that inhabit rivers and streams.

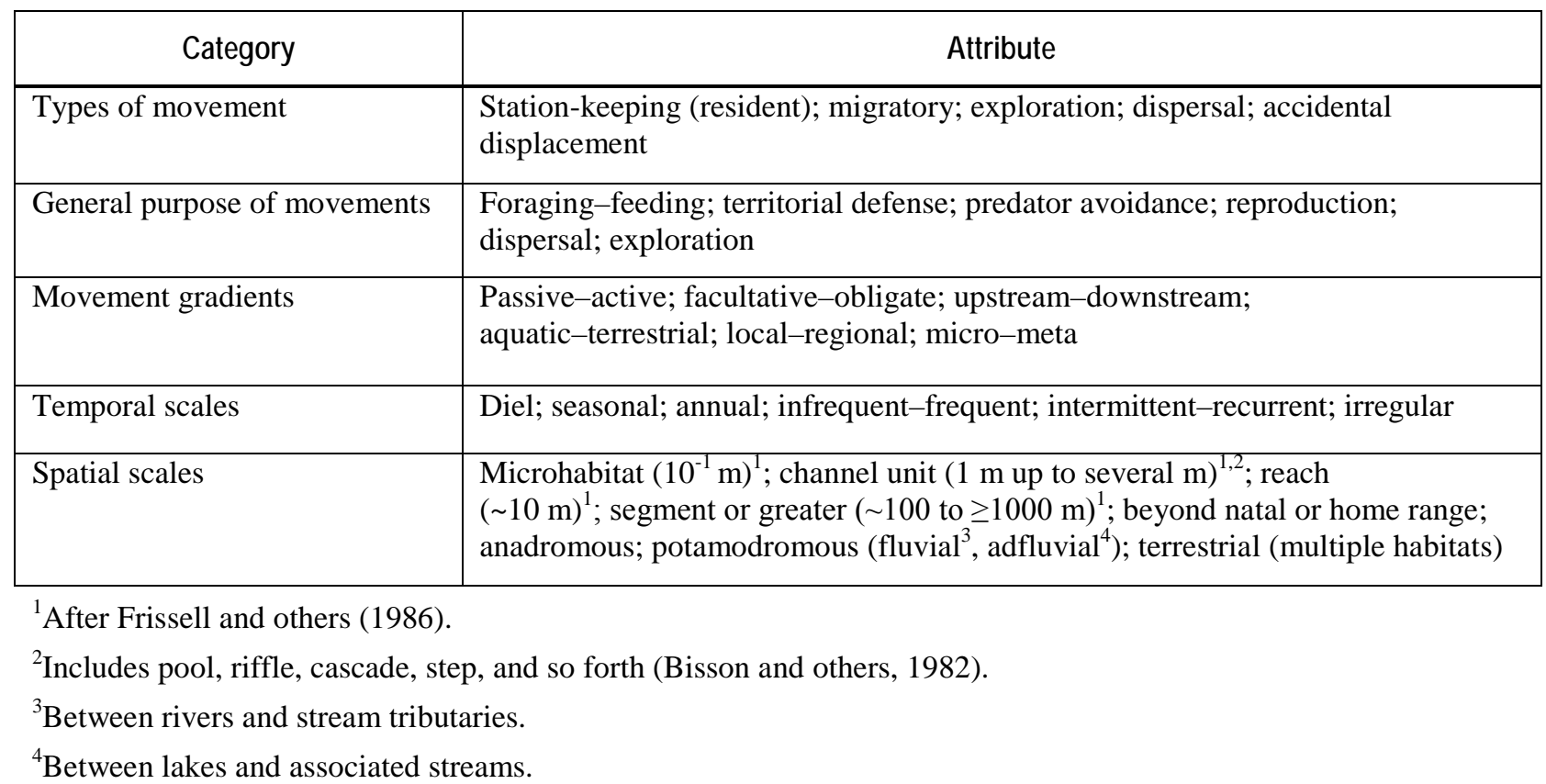


Table 2. General modes of aquatic organism movement categorized by taxonomic group and life stage.

[All modes of movement not necessarily expressed by all subgroups within each general taxonomic group. Life stage: GA, gilled-adult; T, transformed]

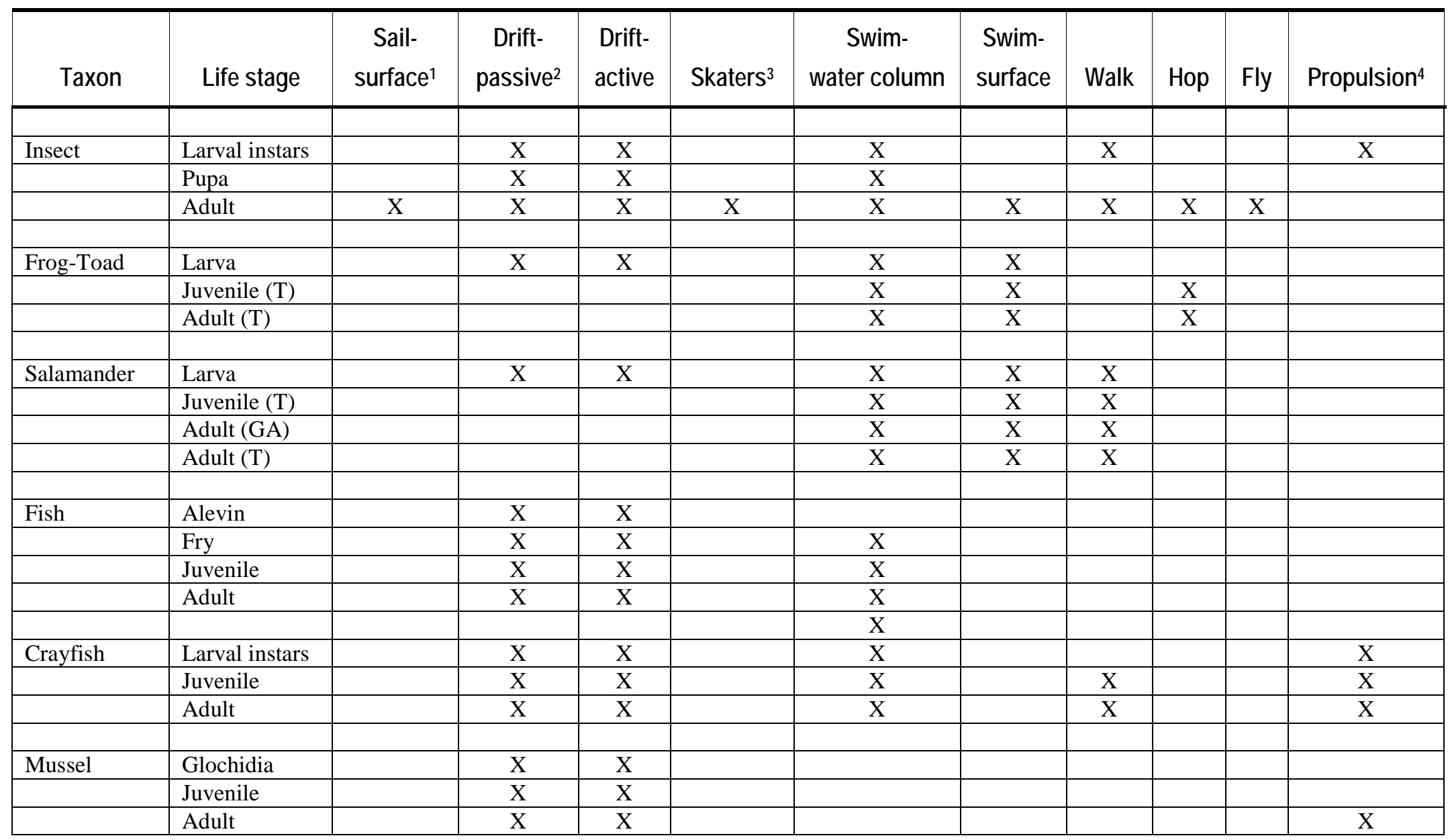

${ }^{1}$ Skimming across water surface achieved by adults raising their winglets.

${ }^{2}$ Movement in this context caused by some condition, event, force, or influence external to the individual.

${ }^{3}$ Surface-water movement without breaking through the film created by surface tension; essentially walking on water.

${ }^{4}$ Insect (Odonates): movement created by expelling water from an abdominal chamber; Crayfish: movement created by the rhythmic extension and flexing of abdominal muscles; Mussel: movement of muscular foot associated with anterior and posterior pedal retractors. 
Table 3. Examples of aquatic organism mobility by life stage.

\begin{tabular}{|l|l|l|l|}
\hline Mobility & Habitat & \multicolumn{1}{|c|}{ Group } & \multicolumn{1}{c|}{ Life stage } \\
\hline & & & \\
\hline Limited & Aquatic & All & embryo $^{1}$ \\
\hline & & Crayfish & hatchling $^{3}$ \\
\hline & & Fish & alevin $^{3}$, yolk-sac lava \\
\hline & & Insects & $\mathrm{pupa}^{3}$ \\
\hline & & Mussels & glochidia $^{2}$, juvenile \\
& & , adult \\
& \\
\hline & & & \\
\hline Active & Aquatic & Amphibians & hatchling, larva \\
\hline & & Crayfish & juvenile, adult \\
\hline & & Fish & fry, juvenile, adult \\
\hline & & Insects & Larva \\
\hline & & Salamanders & gilled-adults \\
\hline & & & \\
\hline & Terrestrial & Amphibians & metamorphosed juveniles and adults \\
\hline & & Insects & transformed - emergent adults \\
\hline & & & \\
\hline
\end{tabular}

${ }^{1}$ Passive mobility.

${ }^{2}$ Mobility associated with movement of host fish species.

${ }^{3}$ Limited active mobility, but typically mostly stationary.

\section{General Model of Aquatic Organism Movement and Passage Impairment Impacts}

Based on the general movement characteristics of fish, amphibians, aquatic insects, crayfish, and mussels, we have created a simplified model of potential impacts to populations at culverts with passage impairment (fig. 1). The model defines the location of the population and direction of organism movement; the category (that is, resident, disperser-explorer, migratory) and spatial extent of movement (that is, microhabitat, channel unit, reach, segment, >segment); four impact scenarios; and seven types of potential impacts. Potential impacts to populations associated with each of the scenarios are summarized in text boxes on the following pages. 

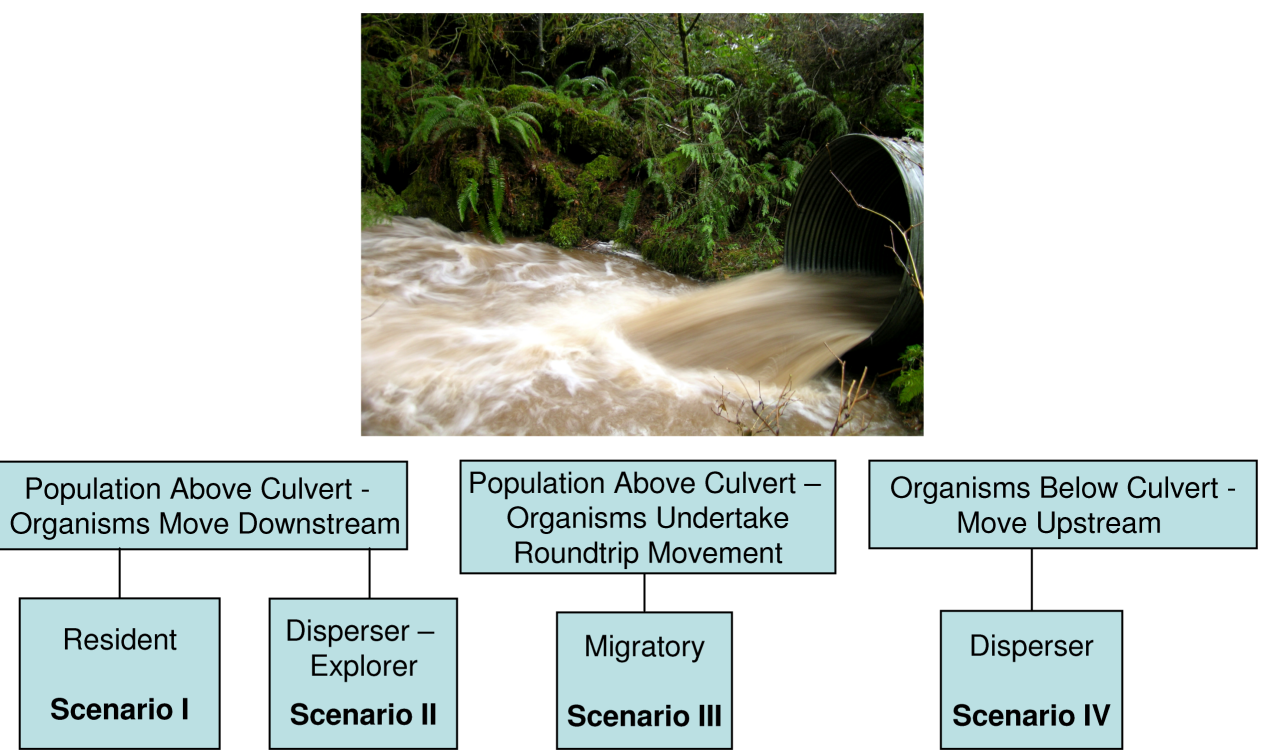

Figure 1. General model of potential effects of the presence of culverts on aquatic organism populations. Culvert photograph by David Leer, Oregon State University.

General Model Impact Scenario I. - The population upstream of the culvert comprises resident organisms that move relatively short distances and do not necessarily move downstream. If individuals do move downstream through a culvert they are most likely able to return upstream. We assume that downstream movement through the culvert primarily is associated with naturally occurring events that displace individuals, causing decreases in population size of short duration. If the loss of individuals from the population were to become relatively frequent, and if the return of individuals upstream were restricted or curtailed, then the population will become isolated from downstream populations and susceptible to population-level genetic effects, such as genetic drift and loss of genetic diversity. 
General Model Impact Scenario II.-Some individuals within populations do actively emigrate as a natural response to the limited availability of suitable habitat for all individuals recruited into the population (that is, density-dependent emigration). The loss of these individuals could cause short-term decreases in population size, although this decrease in abundance probably will be reversed after the next period of successful reproduction and recruitment. Exploring individuals who undertake irregular-erratic roundtrip movements also do not generally affect the overall status of a population. Although these individuals leave the population, they do so for a short period of time and then return. It is possible that the presence of a culvert with restricted or complete passage impairment would affect the return of these exploring individuals, which in turn could negatively affect the above culvert population; and the severity of impact would be directly related to the number of individuals in the population undertaking such roundtrip excursions.

General Model Impact Scenario III.- The severity of the effects of passage impairment appears to be highest for populations upstream of culverts with individuals that migrate beyond their natal location to complete their life-history. In this scenario, the habitats upstream of the culvert are used by reproductive adults and early life-stages (for example, embryos, youngof-the-year, juveniles), and the effects on the population increase with increasing levels of passage impairment. As the number of returning migratory adults decreases, so to does recruitment into the upstream-culvert population and the number of juveniles migrating downstream. Continued recurrence of the restricted ability of individuals within this population to complete their migratory life history could eventually lead to the extirpation of this population from upstream-culvert habitats. If reproductive habitat is available downstream of the passage-impaired culvert, then the migratory population may re-establish downstream; however, if no such habitat is present downstream then this population and migratory species could be locally extirpated.

General Model Impact Scenario IV.--Individuals dispersing upstream from downstream habitats perform the important functions of recolonizing vacant upstream habitats and contributing to the maintenance of the genetic integrity and persistence of upstream populations. It generally is assumed that the fulfillment of these functions is jeopardized when the upstream movement of these individuals is restricted or eliminated causing upstream-culvert populations to become fragmented and isolated from downstream populations; erosion of the genetic integrity of upstream populations over time; decreases in effective population size; and eventual extirpation of the population from upstream habitats. 


\section{Assessment of the Relative Vulnerability of Taxa Groups to Passage Impairment}

We have summarized the results of several studies that have investigated the effects of culverts and other road-stream crossing structures on various groups of aquatic organisms (APPENDIX). We found these summaries to be useful for illustrating potential impacts associated with passage impairment and habitat loss; and the variability of impacts related to species, life history, and life stage. We also found that in some cases, passage impairment at culverts and other road-stream crossing structures may benefit populations of native species. Based on the results of these and other studies, as well as the summaries and tables of the general movement characteristics and patterns for each taxa group, we have projected the potential impacts to each group of the restriction or elimination of upstream movement at culverts and other road-stream crossings.

1. Fish:

- Potential impacts vary, but can be quite high for vulnerable species based on the following:

- The types and patterns of movement within this taxa group are quite diverse; however, all species and life stages are restricted to aquatic habitats;

- Spatial and temporal variability of movements range from limited-localized and of short duration to movements over large spatial and long temporal scales;

- Species are differentially susceptible to barriers to upstream movement and this vulnerability, in general, increases relative to increasing spatial mobility, timing of movement, and the amount of time required to complete the movement (for example, species that are anadromous, and species that migrate wholly within freshwater).

2. Amphibians:

- Potential impacts low to moderate based on the following:

- The larval movement of many stream breeding species is relatively limited and localized;

- Most species have a terrestrial life-stage (juvenile and adult) that allows for overland movement and migration;

- Vulnerability is partly related to watershed complexity; species restricted to watersheds with few tributaries and limited stream branching are generally more susceptible to passage impairment than species in more complex watersheds;

- Results from studies examining susceptibility to barriers to upstream passage movement have been mixed.

3. Aquatic Insects:

- Potential impacts low based on the following:

- Activity and range of movement of most species is limited and localized;

- Downstream drift is the primary mechanism for the longer downstream movements of aquatic life stages;

- Many species have an adult terrestrial life stage capable of flight which can circumvent the potential effects of passage barriers;

- Upstream population density has been shown to be maintained, in part, by recruitment from upstream oviposition by non-drifting individuals. 
4. Crayfish:

- Potential impacts low to moderate based on the following:

- Most species in this group are entirely aquatic;

- Individuals tend to have relatively small home ranges;

- Have long periods of limited and localized activity followed by episodic long distance dispersal upstream and downstream;

- Evidence indicates that some species can be susceptible to barriers of upstream movement.

5. Mussels:

- Potential impacts low to high but equivocal based on the following:

- Group is entirely aquatic;

- Juveniles and adults highly sedentary;

- Larve (glochidia) have pseudo-mobility in that they attach to fish hosts during this short life stage;

- Susceptibility of this group to upstream passage barriers likely a function of the susceptibility of their hosts.

Although various species and populations within each taxa group can be potentially affected by road-stream crossing barriers that restrict upstream passage and movement, fish, in our estimation, are the most vulnerable to the overall effects related to the partial restriction or elimination of upstream movement in streams. Jackson (2003) also considers freshwater mussels to be highly vulnerable due to the reliance of glochidia on fish hosts and because of their endangered and threatened status in the United States and Canada (Williams and Williams, 1993; Lydeard and others, 2004; Mock and others, 2010). However, in any attempt to estimate the potential level of vulnerability of a particular population to passage impairment or loss, regardless of group or species, answering the following three basic questions may be useful:

1. Is the population fully aquatic at all life stages or does the population have a terrestrial life stage that could allow circumvention of potential negative impacts due to restriction or loss of upstream movement?

2. Is the population comprised of a species listed as threatened or endangered?

3. Are habitats upstream of a culvert or other road-stream crossing structure important for the completion of a life stage or life stages critical to the continued viability and survival of the population? 


\section{Four Methods for Assessing Aquatic Organism Passage and Restoration Effectiveness}

Restoration of aquatic organism passage through modification or replacement of roadstream crossing culverts and other structures represents one of the Nation's largest investments in aquatic ecosystems. Current (2008) USFS policy specifies stream simulation as the preferred method for passage restoration design wherever feasible (U.S. Forest Service, 2008). The value of this design method and of restoration in general has not been fully or systematically evaluated. Therefore many questions remain about its effectiveness. For example: (1) has restoration benefitted native aquatic species; (2) has restoration of passage increased the chance that nonnative aquatic species will invade; and (3) what is the evidence required to address these questions? These and other questions are part of a national effort to produce guidelines for determining passage impairment at road-stream crossing structures, prioritize passage barrier removal, and monitor the effectiveness of restoring aquatic organism passage [see Kemp and O’Hanley (2010) for a recent synthesis of evaluation and prioritization techniques and procedures].

There are several ways to attempt to restore stream connectivity and aquatic organism passage through road-stream crossing structures (U.S. Forest Service, 2008, chapter 3, appendix B). Regardless of what method is used, the primary focus of stream restoration efforts should be to reconnect high-quality stream habitats isolated by culverts or other road-stream crossing structures that act as passage barriers to aquatic organisms (Roni and others, 2002; Pess and others, 2004). To do this requires that structures that act as barriers be identified and then prioritized relative to their overall ecological importance, and feasibility and cost of restoration (Roni and others, 2002; Clarkin and others, 2005). Any strategy for the replacement or redesign of a road-stream crossing structure should include clear identification, articulation, and prioritization of objectives and a thorough inventory of site-specific and basin-wide conditions including: (1) identification of passage impediments-blockages; (2) assessment of the physical conditions (including longitudinal and channel cross section profiles, bed material assessments; see Gubernick and others, 2003) at the site of the culvert or road-stream crossing structure; (3) stream habitat quantity and quality; (4) presence-absence of aquatic species of interest upstream and downstream of structures at passage-impaired sites; and (5) selection of a design determined to be the most site-appropriate for restoring connectivity and passage (Roni and others, 2002; Gubernick and others, 2003).

Given these criteria, it is evident that a "tool kit" of useful methods is required for evaluating the level of disconnection and passage impairment at individual sites, for documenting and assessing habitat characteristics and conditions, and for assessing and monitoring the effectiveness of reconnection and passage restoration efforts. For example: (1) Hansen and Reeves (U.S. Forest Service, Pacific Northwest Research Station, Corvallis, Oregon, unpub. data) used PIT tag technology to assess how well the replacement of three culverts in an Oregon Coast Range watershed improved the upstream passage of juvenile anadromous salmonids, and if the design criteria for the new culverts were adequate for fish passage; and (2) Gregory and others (2004) used mark-recapture of juvenile cutthroat and steelhead trout staintagged with Alician blue dye to document the effectiveness of several retrofit designs in improving the movement of fish through previously passage-impaired culverts. The importance of these types of studies is highlighted by Price and others (2010) who evaluated fish passage at 77 randomly selected new and repaired culverts in the Puget Sound region of Washington State. 
Their evaluation found that 23 (30 percent) of the culverts were passage barriers due primarily to noncompliance with the provisions of their construction and installation permits. They concluded that there needed to be better mechanisms for ensuring compliance with culvert design standards and construction, and for more effective monitoring of fish passage restoration at repaired, retrofitted, replaced, and newly constructed road-stream crossing structures.

In this section, we describe and examine the utility of four classes of methods (Individual Movement, Occupancy Models, Abundance [Demography], and Molecular Genetic Markers) that we think will be useful for identifying and evaluating (1) the level of passage impairment at culverts and road-stream crossing structures, and (2) the ecological conditions that either rule-out or support repairing or replacing them. The methods also will be useful for documenting and assessing the effectiveness of stream connectivity and passage restoration efforts. We also offer advice on how to implement each of these methods for these purposes.

\section{Individual Movement}

Prepared by Robert Hoffman (U.S. Geological Survey), Jason Dunham (U.S. Geological Survey), Ivan Arismendi (Oregon State University)

Related article: Stream Notes, October 2011:

http://stream.fs.fed.us/news/streamnt/pdf/SN_10_11.pdf

Workshop Presentation by Theodore Castro-Santos (U.S. Geological Survey) and Keith Nislow (U.S. Forest Service):

http://www.fsl.orst.edu/geowater/PEP/aopw/castro-santos

Tracking individual movement is a useful and straightforward tool (Turchin, 1998) for evaluating aquatic organism passage at road-stream crossings. Application of this method involves the capture, marking or tagging, release, and recapture or relocation of individuals at some later time to detect movements. Depending on the marks or tags used (for example, fin clips, external and internal anchor tags, Passive Integrated Transponder [PIT] tags), individuals may or may not be uniquely identifiable. We have identified three potentially questionable assumptions that might be made when working with marked and tagged individuals, and offer some basic caveats to each one.

- Assumption 1.-Marked and tagged individuals can be recaptured or relocated at a level or rate that allows for a meaningful (quantifiable) assessment of movement. The number of recaptured or tracked individuals typically is less than the number of individuals originally marked or tagged. For example: the average recapture rate in a study conducted by Warren and Pardew (1998) was 18-21 percent, spring and summer, respectively, and 19-24 percent (range $=15-47$ percent) in a study conducted by Roghair and Dolloff (2005). The proportion of marked fish recaptured in a study conducted by Burford and others (2009) averaged 0.63 (range $=0.12-0.95$ ) in reference reaches and 0.37 (range $=0.00-0.84$ ) in culvert reaches. This lower rate of recapture can be attributed, in part, to tag or mark loss, failure to detect or recognize tags or marks, mortality of tagged or marked individuals, or movement of individuals outside of the study area. Based on these considerations, it is possible to roughly estimate an expected number of recaptured individuals. If we assume that we initially mark or tag a sample of 100 individuals and that the fraction of individuals retaining visible marks or tags is 0.9 , survival is 0.9 , the fraction of marked or tagged individuals staying in the study area is 0.9 , and the probability of recapture is 0.9 , then we would expect to recapture about 66 individuals $(=100 * 0.9 * 0.9 * 0.9 * 0.9)$. This is a very optimistic scenario. If we sample with 
the same probabilities, but reduce the probability of recapture to 0.3 (a bit more realistic), the expected number of recaptures is $22(100 * 0.9 * 0.9 * 0.9 * 0.3)$. If more marked and tagged individuals move out of the study area (for instance the fraction of individuals staying in the study area is 0.7$)$ and the recapture probability remains relatively low $(0.3)$, then there will be even fewer expected recaptures $(100 * 0.9 * 0.9 * 0.7 * 0.3=17)$. If we are interested in the probability of an individual moving through a road-stream crossing structure, the required number to detect such movements may be even greater. This is because only a fraction of the total number of marked individuals may make such movements. For example, assume the probability of an individual moving through a structure is 0.30 . Given the scenarios above for expected recaptures $(66,22,17)$, the estimate of the number of expected recaptures of fish that moved through the structure would be 30 percent of each of these numbers, or only 33, 7 , and 5 individuals, respectively. These are rough approximations of expected numbers of recaptured individuals, and other factors may influence actual results. It is easy, however, to see that failure to detect movements through road-stream crossing structures may be due to a limited number of marked or tagged individuals recaptured or relocated, even if the initial samples of individuals were relatively large.

- Assumption 2.-Movement through a road-stream crossing structure is constrained only by the characteristics of the structure. There are various factors unrelated to a road-stream crossing structure that may negatively influence movement. For example, lack of suitable upstream habitat or habitat characteristics, such as water temperature, dissolved oxygen concentration, $\mathrm{pH}$, and substrate composition that are less than optimal, could be responsible for or contribute to limiting the passage of individuals through a structure. Detection of movement also can be influenced by the timing and extent of sampling. In all taxonomic groups and species the movement characteristics of individuals vary temporally, spatially, and by life stage. The sampling schedule of a study must, therefore, coincide with the movement characteristics of the species of interest. Some species of interest also may be semi-aquatic, having a terrestrial or flying life stage that allows them to move within and along the riparian area of a stream or overland (characteristic of juvenile and adult frogs, toads, and salamanders, and many adult aquatic insects), allowing them to circumvent use of a road-stream crossing structure as a movement pathway. In these cases, we could choose to focus entirely on the aquatic life stage(s) of a species of interest or include a terrestrial marking and tracking component as part of the overall movement study design.

- Assumption 3.-Marking and tagging do not influence individual survival or behavior. Murray and Fuller (2000, table 2.1, p. 20-22) has reviewed the results of past studies that have examined the effects of the application of tags and the clipping-removal of fins on the survival and behavior of fish. The studies found that tagging had relatively no significant effect on survival (15 of 19 studies) or behavior (3 of 3 studies). Conversely, however, more studies found that fin clipping-removal did negatively effect the survival (8 of 13 studies) and behavior (1 of 1 study) of marked fish. However limited the inference of the results of these studies might be, we suggest that the application of marks and tags be accomplished using methods designed for minimizing their impact on the survival and behavior of tagged and marked individuals. 


\section{Movement Study Example: Mark-Recapture with Electrofishing and Trapping}

Burford and others (2009) assessed the passage of native westslope cutthroat trout (Oncorhynchus clarkii lewisi) and nonnative brook trout (Salvelinus fontinalis) through culverts in the upper Clearwater River drainage system, western Montana. Using FishXing version 3.0 (Furniss and others, 2008) and guidance from Clarkin and others (2005), they initially documented passage impairment at 47 culverts and measured or estimated 11 culvert- and stream-associated parameters at 45 of them. They also documented fish population characteristics by capturing fish within 90-m reaches upstream and downstream of a subset of 23 study culverts using single-pass electrofishing (Kruse and others, 1998). This was followed by the implementation of a fish passage experiment at 12 study culverts that included a treatment and reference reach at each culvert (table 4).

Table 4. Details of the basic design elements of the Burford and others (2009) experiment.

\begin{tabular}{|c|c|c|}
\hline Design element & Treatment reach & Reference reach \\
\hline Downstream boundary & Near downstream end of plunge pool & Located at downstream end of reach \\
\hline Upstream boundary & $\begin{array}{l}\text { Within } 5 \text { m upstream of upstream culvert } \\
\text { opening }\end{array}$ & $\begin{array}{l}\text { At the downstream boundary of the } \\
\text { treatment reach }\end{array}$ \\
\hline Length & $17.3-33.8 \mathrm{~m}$ & $17.3-33.8 \mathrm{~m}$ \\
\hline Culvert position & Approximately mid-reach & none \\
\hline Channel blocks & $\begin{array}{l}\text { Downstream and upstream ends of reach } \\
\text { with 6-mm wire mesh across channel }\end{array}$ & $\begin{array}{l}\text { Downstream and upstream ends of reach } \\
\text { with 6-mm wire mesh across channel }\end{array}$ \\
\hline Initial fish capture & Electrofishing & Electrofishing \\
\hline Fish identifier (mark) & Pelvic fin clip & Pelvic fin clip \\
\hline Release location after mark & Downstream end of designated reach & Downstream end of designated reach \\
\hline Trap position & Upstream boundary of reach & Upstream boundary of reach \\
\hline Duration of trap monitoring & 72 hours after release & 72 hours after release \\
\hline
\end{tabular}


Burford and others (2009) successfully documented the presence and abundance of fish upstream and downstream of culverts at a subset of 23 of the 45 culverts analyzed using FishXing. The results of their mark-recapture passage experiments indicated that the upstream movement of marked individuals, regardless of size, was significantly lower, overall, through culverts (average recapture rate proportion $=0.37$ in culvert reaches) than through natural stream reaches (average recapture rate proportion $=0.63$ in reference reaches); although passage success was not significantly associated with culvert characteristics, except for the negative association of outlet drop and the passage success of individuals less than $100 \mathrm{~mm}$ in length.

Additional studies that provide useful examples of and guidance for the use of markrecapture as a method for investigating crossings as passage barriers and the movement of aquatic organisms through culverts include: (1) Bouska and Paukert (2010), Great Plains stream fish assemblages; (2) Coffman (2005), common fish species of the Mid-Atlantic Highlands region of the United States; (3) Gregory and others (2004), juvenile cutthroat (Oncorhynchus clarkii) and steelhead (Oncorhynchus mykiss) trout; (4) Nowicki and others (2008), non-culvert study using mark-recapture methods for studying crayfish movement in streams; (5) Sagar (2004) and Sagar and others (2007), larval coastal giant salamander (Dicamptodon tenebrosus) movement in small streams of the Oregon Coast Range; and (6) Warren and Pardew (1998), movement of fish (darters, minnows, sunfish, topminnows) through nine crossings in eight streams in the Ouachita National Forest (Ouachita River drainage), Montgomery County, Arkansas.

Movement Study Example: Mark-Recapture and Passive Integrated Transponder (PIT) Tags.

Roghair and others (2010) examined the movement of creek chub (Semolitus atromaculatus) at three crossings with differential passage impairment in the Daniel Boone National Forest, eastern Kentucky. The purpose of their study was to compare the effectiveness of using fin-clip mark recapture and PIT-tag tracking methods for assessing movement. Each study site included two, 200-m reaches downstream of a culvert and one, 200-m reach upstream of the culvert. One antenna for tracking PIT-tagged fish was installed at the 200-m point between the two downstream reaches; a second antenna was installed at the downstream opening of the culvert; and a third antenna was installed at the upstream opening. Fish in the two downstream reaches were fin-clipped or implanted with tags, March-April, and released. Recapture attempts for fin-clipped fish (recapture rates not reported), using electrofishers, were conducted JulyAugust. The movements of PIT-tagged fish were continuously monitored by the antennas. The preliminary results of this study indicate that the PIT-tag technology was useful for detecting the movements of fish not detected using the mark-recapture technique, and for detecting the movement of fish from the reach just downstream of the culvert into the reach upstream of the culvert. Investigators also discussed the greater monetary, maintenance, and time-investment requirements of the PIT-tag method.

See, also, the following studies for additional examples of the use of PIT-tags to study movement and passage at crossings: (1) Blank and others (2006), used PIT tags and fixed antennas placed at five culverts to assess and monitor fish passage through the culverts; (2) Cahoon and others (2007), examined fish passage in the drainage of a high-gradient stream system in Montana; (3) Hansen and Reeves (US. Forest Service, Pacific Northwest Research Station, Corvallis, Oregon, unpub. data) used PIT tags to document the movement of juvenile anadromous salmonids through three replaced culverts; (4) Hudson and others (2009), assessed and monitored the movement and passage efficiency of Pacific lamprey (Lampetra tridentate), 
adult salmon (Oncorhynchus spp.), and steelhead and coastal cutthroat (Oncorhynchus clarkii clarkii) trout through a culvert as part of a culvert replacement project; and (5) Lang and others (2004), used PIT tags and fixed antennas to remotely detect and document the passage of adult coho salmon (Oncorhynchus kisutch) and steelhead through culverts on two northern coast California streams.

\section{Occupancy Models}

Prepared by Michael Adams (U.S. Geological Survey)

Workshop Presentation by James Peterson (U.S. Geological Survey):

http://www.fsl.orst.edu/geowater/PEP/aopw/peterson

In the world of occupancy models, everything is divided into patches. Our objective is to know whether a set of patches is occupied and to know what factors predict the occupancy of these patches. Our ability to observe occupancy is limited by the possibility that we could fail to detect a species that is present, which means that the closest we can get to our objective via direct observation is to detect or not detect the species in each patch. We use occupancy models to estimate the probability that a patch is occupied given the observations we have made and other information that we have about the patches surveyed.

When we are interested in the presence of a species of interest in a length of stream divided by a barrier, we can view the length of stream upstream and the length of stream downstream of the barrier as two patches. Our expectation is often that a species that was limited to the downstream patch will be able to use the upstream patch when the barrier is removed. What constitutes a barrier may vary among species and may not align with our own perception, so there is uncertainty about whether our attempt to remove the barrier was effective. There also is uncertainty about the motivation of the species to move past the former barrier. Thus, we have a question: did our attempt to remove the barrier result in a change in the occupancy of the patch we are interested in for one or more species? We illustrate how occupancy models can address this question by considering one of the most common situations encountered in evaluation of aquatic organism passage.

A common situation is that we wish to know whether a species that was confined to a downstream patch occurs in both the upstream and downstream patches post barrier removal. If we find the species upstream, then the barrier removal was a success. But what if we do not find the species upstream? In this case, it is possible that the barrier removal was a failure or that we simply failed to detect the presence of the species in the upstream patch even though that species was present.

Failure to detect the presence of a species underscores the notion that surveys for animals are rarely perfect. The fact that species are sometimes not detected when they are actually present biases statistical analyses and can lead to erroneous conclusions. Occupancy models are useful because they offer a means to reduce or eliminate the statistical bias caused by imperfect species detection. They simultaneously measure and adjust for the rate at which we fail to detect species that are present. The primary function of occupancy models is to estimate and incorporate the probability of detecting a species that is present into an estimate of the probability of occupancy; but their real utility lies with their ability to evaluate the influence of other variables on occupancy. These variables could include characteristics of the restored crossing or habitat. 
If we were only assessing barrier removal at a small number of streams, we might develop an intensive survey protocol that seeks to minimize the chances of a false negative (that is, not detected when actually present). Because we are removing barriers at a large number of streams, using such an intensive protocol could be expensive. It is therefore desirable to come up with a defensible means of determining effectiveness of barrier removal across a large number of streams. This is where occupancy models can offer an efficient alternative.

\section{Implementation}

The primary characteristic of an occupancy study design is the use of repeated surveys for the presence of a species at some or preferably all patches selected for sampling. It also is typically necessary that these visits occur during a time interval during which the occupancy status of the patch is assumed not to have changed (although this assumption can be relaxed for more complex models and sampling approaches). This means the species has not colonized or become locally extinct in-between sampling efforts. Given these conditions, these repeat efforts provide the information needed to estimate and incorporate the probability of detection into a model of patch occupancy. Imagine two surveys of a stream reach located within a patch: one detects fish and one does not. The length of the reach is large relative to the daily movement of the fish and the surveys occur on consecutive days, so we assume that the fish detected during one survey were present during the other survey. Thus, for this reach, we failed to detect fish that were present in one-half of the surveys. When such data are collected at many sites, a rate of false negatives can be established and, conversely, the probability of detecting a species that is present can be estimated (MacKenzie and others, 2006). The key design elements are the use of multiple surveys and the assumption that occupancy did not change between surveys. Because the probability of detection is incorporated in the model, it is not necessary that the surveys be particularly intensive.

It is important to understand that occupancy models are used to estimate probabilities and effect sizes over multiple patches. The estimates are made for each patch analyzed but it is not appropriate to use occupancy models to analyze a single patch or even a small number of patches.

There is no set rule, but occupancy models probably begin to become appropriate when we have at least 20 patches to consider and in many situations, they may not be very useful until at least 50 patches are surveyed. The number of patches needed depends on the rate of occupancy, the rate of detection, and the number and structure of the variables used to help predict these rates. An occupancy model will not tell us whether we missed a species at a particular patch but will estimate the probability that a patch is occupied. For example, if we do not detect fish at 10 out of 50 patches surveyed, the output of the model can help us determine how many of those patches might actually have fish present and, if we incorporate covariates of occupancy and detection, the output can help determine which of the 10 might be the most likely to be occupied.

\section{Simple Example}

Let us say that we want to know the success rate of barrier removal in a set of 50 streams in the Oregon Coast Range. We define success as the presence of fish upstream of the barrier and we already know that fish are present downstream of the barrier. We assume in this case that fish are not present upstream of the barrier prior to removal. We need to define the size of the upstream patch to be sampled so that it is ecologically relevant and meets the assumptions of the 
model. In both cases, a stream length that is twice the average weekly movement of the fish seems appropriate. At that scale, multiple individuals should be present if a population exists and it is unlikely that the occupancy status of the reach would change over short-time periods. We will survey for fish by electrofishing, and one pass will be considered one survey. We suspect that detectability changes over the course of the year, so we will limit sampling to July, August, and September, and will include day of the year as a covariate in the model. We suspect that the pool:riffle ratio and substrate composition relate to both the probability of detection and the probability of occupancy. Finally, we hypothesize that the length of the stream simulation channel has a negative correlation with the probability that the upstream patch is occupied after barrier removal.

Because we have several covariates in this design, it is important to design surveys to both limit variation in detection probability and to allow us to model any other variation in detectability. This will allow for more efficient estimation of detection probability when variability is high and sample sizes are limited, which is often the case. We have already mentioned that we will only sample during 3 months of the year. This is a design-based method to limit variation in detectability. We also mentioned that we will include a covariate of detection in the model that codes for day of the year. This is a model-based method to account for variation in detectability. For the model-based approach, it is not enough to simply include the covariate; we need to assure ourselves that we can estimate the effect of these covariates with the data we collect. If we ignored this issue, we might choose to simply send a crew to each patch and have them conduct two surveys during one visit. We would treat the two surveys as the repeat observations that are necessary for an occupancy model to incorporate the probability of detection. Because the information used to estimate detectability comes from the repeat surveys, it is necessary that the repeat surveys contrast the covariates. The simple design above would yield estimates of the effect of day on detectability, but the effect of day would be confounded with any variation in detectability among sites. The problem is that the observations for any one patch always occur on the same day. Doing two surveys on the same day is cost effective, but is not an ideal design to estimate the effect of day so we will compromise. We will sample most streams by doing two surveys on the same day, but we will randomly choose 12 streams that we will visit on a second day. Because it is relatively easy to do two surveys during each visit, these 12 streams will receive a total of four surveys. We will analyze these data with a single season occupancy model. The output will include estimates of the probability that each site is occupied. We can average these estimates for all or a subset of sites to suggest the proportion of patches that are occupied.

This example relies heavily on the assumption that all downstream patches were occupied and all upstream patches were unoccupied prior to barrier removal. If the occupancy status of the downstream patch is unknown, one possibility is that surveys be conducted to determine presence of the species' of interest and that only sites where these species are determined to be present be used to evaluate the effectiveness of barrier removal. This will allow us to focus monitoring resources on sites where we will get the most useful information. The only shortcoming might be that there could be sites where barriers are removed but where the species of interest were not detected downstream, and we will not have statistical inference to these sites. It is worth noting at this point that there are more elaborate occupancy designs that could accommodate the inclusion of sites where the downstream patch may or may not be occupied prior to barrier removal (see MacKenzie and others, 2006). 
Several Things to Consider About Using an Occupancy Approach:

1. The use of occupancy models only makes sense if there are both occupied and unoccupied patches. Further, occupancy models will tend to be problematic if the occupancy rate is too close to 0 or 1 . They do not perform well for rare or common species.

2. Occupancy models probably will not be useful to evaluate the removal of partial barriers where the upstream and downstream patches are both occupied, but the barrier is thought to reduce movement. This is related to the issue of species' prevalence; they may be too common in such situations, resulting in high rates of occupancy.

3. Occupancy models are only needed if the probability of detecting a species that is present is less than 1. If it is just slightly less than 1, you might want to consider another approach.

4. Patch size is a subjective choice, but should be relevant to the question or management objectives to be addressed. Other considerations will be the relationship of patch size with occupancy rate (smaller patches mean lower occupancy), and with the closure assumption (animals are assumed to remain within the sampled area for all sampling occasions).

5. If only a subset of patches is sampled within the entire sampling frame (for example, you want to know the effect of barrier removal at 100 streams, but you will only sample a subset of streams), you will have a decision to make about the allocation of sampling effort and it will be desirable to optimize the ratio of sites to repeated visits to get the best estimates of parameters in the model (see MacKenzie and others, 2006; chapter 6 and section 7.7).

6. It is always best to consult a biometrician before initiating a study.

\section{Some Fundamentals of Occupancy Models}

1. Models are useful for estimating the probability that patches (sites, habitats, locations) are occupied or unoccupied by a single or multiple species.

2. Failure to detect a species when present is a potential source of error; however, occupancy models can be used to reduce or eliminate this statistical bias.

3. Use of multiple surveys and the assumption that patch occupancy does not change between surveys are key design elements.

4. Models are best used to estimate the probability of occupancy over multiple patches rather than for single or a small number of patches.

5. Minimum number of patches for meaningful model estimation probably is between 20 and 50 .

6. Number of patches required for meaningful estimation depends on (1) rate of occupancy, (2) rate of detection, and (3) number and structure of variables used to predict the rates. 
This discussion of Occupancy Models is based, in part, on the following references that can be reviewed for a more detailed discussion of the use of these models for inferring the patterns and dynamics of species occurrence: Mackenzie and others (2002), Mackenzie and others (2003), Mackenzie and Royle (2005), Mackenzie and others (2006), Pearl and others (2009), Royle and others (2005), and Royle (2006).

\section{Abundance (Demography)}

Prepared by: Jason Dunham (U.S. Geological Survey)

Workshop Presentation by Benjamin Letcher (U.S. Geological Survey): http://www.fsl.orst.edu/geowater/PEP/aopw/letcher-demography

Abundance (demography) can be broadly defined to include a range of biological responses and study methods in ecology (Gotelli, 2008). We focus on the basics: birth, death, emigration, and immigration. These four demographic parameters are the result of growth and survival of individuals, which in turn are driven by a host of individual behaviors (van Horne, 1983; Railsback and Harvey, 2002). Because natural selection acts strongly on individuals, this is the fundamental level at which we understand why individuals act as they do (Gavin, 1991). We do not address individuals explicitly in discussing demographic responses of organisms at crossings. However, we stress that it is important to be mindful of the chain of causality that begins with individual behaviors (and other characteristics) that drive birth, death, emigration, and immigration, and ultimately determine abundance.

Abundance is a natural focus of management or conservation objectives, yet linking abundance to the influences of habitat or passage conditions is notoriously challenging (van Horne, 1983; Fausch and others, 1988; Railsback and others, 2003). This is because the four basic processes that determine abundance at any given time (birth, death, emigration, and immigration) are often not independent of each other, and in fact may be driven by abundance itself (for example, density dependence). Sorting out the influences of these different processes can be challenging because each can be extremely difficult to quantify, let alone abundance (Dunham and others, 2009). Given these challenges, the prospects for applying abundance as an indicator of aquatic organism passage effectiveness seem limited. Indeed, we conclude this is the case; but because abundance is invariably stated as a management or conservation objective and quantified in practice, we give it due consideration.

We focus on abundance rather than estimation of its components, birth, death, emigration, or immigration, because these are typically too expensive or technically challenging to quantify in most practical settings. In other sections of this document, however, there are guidelines for direct (via tracking of marked individuals) and indirect (via genetics) quantification of movement, including emigration and immigration. Estimation of survival is covered by a rich literature and suite of methods that are outside the scope of this review (for example see, Ebert, 1998; Williams and others, 2002; Lee and Wang, 2003; Pine and others, 2003). Programs to estimate survival of aquatic species in relation to passage conditions are operational in some places with the potential for intensive resource conflicts (for example, impacts of large hydropower operations on Columbia River salmon in the Pacific Northwest http://www.fpc.org/). In the context of crossings, we consider the more common situation where abundance, or its common derivative, population density, may be in question. 
Assuming one can accurately estimate abundance in streams (for example, Dunham and others, 2009) the question of how abundance can be influenced by isolation appears simple. If crossing structures restrict movement or isolate populations upstream, abundance will almost certainly be diminished. The best example of this is the case of erosion control dams in Japanese streams, and their impacts on native white-spotted charr (Salvelinus leucomaenis; reviewed by Morita and others, 2009). A host of demographic and genetic studies have shown that populations of this species decrease in abundance when barriers are present. In some cases, abundances are depressed to the point at which dysfunctional characteristics (morphological deformities, inbreeding) are evident. Smaller populations are at risk of extinction, based on predictions from various models and field observation (Morita and others, 2009; Tsuboi and others, 2010). Such impacts would be expected from a wide range of species, especially those that existed at larger population sizes prior to isolation, and those dependent on movement for completing their life histories.

Abundance is often expressed in terms of density-the number of individuals per linear dimension, area, or volume. Population density is an important factor in ecology, being a primary factor determining the nature and strength of intraspecific interactions (van Horne, 1983). In some cases, higher densities can have negative consequences for individuals (Ward and others, 2006), yet in other cases, higher densities may benefit all individuals within a locality, as in the case of freshwater mussel "beds" (Strayer and others, 2004). Impacts of isolation on population density also can be strongly situation- and species-dependent, and therefore difficult to predict. For example, population densities were higher in isolated versus connected populations of trout in the Great Basin of Nevada (Dunham and others, 2002a). This pattern was attributed to the effect of migration on reducing local densities in connected populations. Because population density and body size are often inversely related (Duarte and others, 1987; Grant and others, 1998), the smaller sizes of individuals in isolated locations also may be an explanation for increased densities. Populations may support larger numbers of small individuals or smaller numbers of larger individuals. If body size is tied to isolation, then population density also should be influenced.

Changing species composition associated with isolation also may influence densities of interacting resident species, as reported by Tsuboi and others (2010). In cases where migratory species are impacted, both abundance and richness is expected to be higher downstream of barriers (Katano and others, 2006). These effects can be particularly pronounced if abundance or density is recorded in the immediate vicinity of a barrier that concentrates individuals (for example, during times when individuals are attempting to migrate upstream). Finally, impacts of isolation can vary among locations, particularly in relation to habitat size (Morita and Yamamoto, 2002; Neville and others, 2009).

\section{Conclusion}

It is critical to consider the specific processes influenced by passage impairment (isolation) or restoration (connectivity) and to develop specific predictions about how abundance or density should respond. Based on the examples presented here, there is no reason to expect a simple or universal response to passage impairment or restoration. Therefore, it is critical to develop a-priori hypotheses with testable predictions about how abundance or density should respond in relation to passage impairment or restoration. Simply comparing these measures in relation to passage may not reveal impacts, let alone reveal useful demographic insights. 
We do not unequivocally discourage measurement of abundance or density as part of monitoring effectiveness of aquatic organism passage, but strongly caution that it can be an inconsistent response. For example, Dunham and others (2002b) found increased densities of stream-living trout upstream of passage barriers, presumably due to limited expression of migratory life histories. In another recent example, Nislow and others (2011) found the opposite pattern: passage impairment was associated with decreased abundance upstream of barriers. Part of the discrepancy in results among studies could be due to consideration of raw abundance versus more standardized measures such as density. These two measures can provide completely different answers regarding the impacts of barriers. Thus, it is critical to at least develop a series of testable hypotheses about processes influencing demography, and ultimately abundance or density before conducting a study (Dunham and others, 2002b; Nislow and others, 2011). Identifying a study approach that can test predictions from these hypotheses while avoiding or controlling for confounding factors is essential for obtaining useful insights. As shown above, expectations of abundance and density can vary considerably, depending on the situation.

We also recommend that abundance or density be considered in concert with other methods, such as individual movement, occupancy, or genetics so that stronger tests of hypotheses about passage are possible. For example, Burford and others (2009) could not explain variability in density in relation to passage, but patterns of individual movement revealed that culverts restricted movement, and that this result had a biologically plausible explanation.

\section{Molecular Genetic Markers}

Prepared by Helen Neville (Trout Unlimited)

Workshop Presentation by Helen Neville and Benjamin Letcher (U.S. Geological Survey): http://www.fsl.orst.edu/geowater/PEP/aopw/neville http://www.fsl.orst.edu/geowater/PEP/aopw/letcher-sibship

Molecular genetic markers are sequences of DNA that indicate patterns of relatedness among individuals and populations (Avise, 2004). To date, applications of these markers to evaluate the specific question of aquatic organism passage are limited, but existing evidence suggests that markers offer a powerful alternative to more commonly applied methods. The efficacy of these measurements may depend on the vagility (that is, the capacity or tendency to move about or disperse in a given environment) of the species, the life history stage of interest (that is, adults vs. juveniles, or resident vs. migratory), and the landscape context of the restoration site. In many scenarios, however, one or a combination of markers and analyses could be applied successfully to characterize individual movement and population impacts with relatively little effort. Additionally, genetic approaches are uniquely effective for monitoring hybridization with non-native species, which is essential in many cases where invasion may be likely after connectivity has been restored.

Genetic data can be useful for monitoring various biological questions, including the fine-scale movement of interest when evaluating the success of culvert restoration projects. Relative to the more intensive efforts and long field seasons required for studies of individual movement, demography, and even occupancy, genetic approaches can be implemented with limited field sampling and often at less expense. Furthermore, genetic data can provide evidence of movement that is difficult or impossible to capture with these other methods, such as longdistance movement or pulses of movement outside the duration of a field study. Finally, the rapidly increasing availability of molecular genetic markers and analytical methods allows for 
applications suited to a wide range of questions about aquatic organism passage. Here, we consider a subset of these possibilities that we view to be most applicable for evaluating aquatic organism passage.

\section{Population-Level Approaches}

When discussing genetic analyses, it is often useful to distinguish between "populationlevel” and "individual-level” approaches. Population-level approaches can be the easiest and least expensive to implement for localized questions about movement, such as evaluating passage for specific restoration projects. Determining exactly what constitutes a "population" is not always straight-forward (see below), but for simplicity here we can refer to a group of individuals living in the area of interest (for example, upstream or downstream of the culvert) as a population. This is analogous to the concept of a "patch" as discussed previously in the context of occupancy modeling.

When applied to the question of aquatic organism passage, population-level approaches would evaluate measurements of within-population genetic variability and inter-population genetic differences. For example, if passage is impaired, we may expect genetic variability within populations to decrease. When a formerly large population becomes small and isolated, genetic variability can be lost because a limited number of individuals are left to reproduce. This in essence is a sampling effect. In this sense, the "sample" of adults following isolation is not representative of the population from which it was isolated. The process is repeated each generation as a limited number of breeding adults passes on a limited sample of genetic variability. Thus, the loss of genetic variation should be the result of the size of the initial sample of breeding adults and time since isolation. Conceivably this process can be reversed when passage is re-established, because new breeding adults may come into contact with the formerly isolated population, restoring genetic variability. Another consequence of this gene flow is reduced differences among populations within a network of locations. In short, isolation should lead to decreased numbers of breeding adults, decreased genetic variability within populations, and increased differentiation among populations. Restoration of passage should reverse these impacts.

\section{Individual-Level Approaches}

Whereas population-level approaches provide indirect measurements of dispersal (because movement is inferred based on changes in population genetic characteristics), individual-level genetic techniques, under certain circumstances, can be used to directly evaluate movement. One such approach that is commonly used is the individual assignment test. In this method, the genotypes of individuals are evaluated in relation to the genetic characteristics of a set of potential source populations, where source populations ideally comprise all those from which individuals could have originated. Based on similarities between an individual's genotype and the genetic signature of the source populations, individuals are probabilistically assigned to the most likely population of origin. Movement is evident if an individual is assigned to a population (or location) different from where it was captured. In the case of aquatic organism passage, assignments of individuals can be used to determine if movements are occurring at crossings or in other locations of interest. 
More recently, development of individual-based genetic sibship analysis using pedigree reconstruction is currently being evaluated for determining culvert passage of young-of-year fish (Text Box this page). This approach has similar advantages to assignment tests, but may have even higher power to detect movement. Depending on the distribution and dispersal behavior of the species of interest, sampling needs can be fairly localized and perhaps lessened. The approach is restricted to capturing movement of juveniles, which may be undesirable in some cases but in other cases may be advantageous because this is an age-class that is often neglected in movement studies.

\section{Relatedness reconstruction to assess movement over barrier restoration sites.}

Jason Coombs, Ph.D. Candidate, The Graduate Program in Organismic and Evolutionary Biology, University of Massachusetts, Amherst

Traditionally, answering the question "Are individuals moving across a barrier, and if so in which direction?” would require the use of a capture-mark-recapture (CMR) experimental design. Outlined briefly, individuals would be initially captured, marked with an individual or habitat specific identifier, and returned before executing a second capture event after an elapsed period of time to recapture marked individuals and assess movement rates and directions. However, the advent and advancement of molecular techniques and relationship reconstruction algorithms has made another alternative possible. Like CMR, the populations adjacent to the barrier would be sampled. Unlike CMR, individuals would not be tagged, but instead donate a tissue sample as a source of DNA. Molecular techniques would then acquire individual genotypes which, when run through a relationship reconstruction algorithm, would delineate individuals into full-sibling families. Movement across a barrier would then be determined by whether all members of a full-sibling family were on one side or both sides of the barrier. Directionality of movement could be attained through use of a majority-rule approach, where the side with the greatest proportion of family members is assumed to be the natal patch, and direction of movement would be away from this side. In addition to this key assumption, a second assumes that a parental pair reproduces on only one side of a barrier. Initial data for brook trout (Salvelinus fontinalis) shows these assumptions to be likely, but requires further assessment.

Simulations assessing the accuracy of this method for various population differentiation (DST $=0,0.1,0.25$ ) and movement restriction (two-way, one-way, none) scenarios have been positive, with greater than 95-percent accuracy for assigned movers and directionality achieved for all scenarios. Additionally, the use of this method does not preclude the use of traditional CMR techniques in that individual genotypes can be used as individual identifiers. Furthermore, unlike traditional CMR techniques, this method is able to use information on parent locations during spawning/birth to determine natal patch origin, lessening the dependence on the majority-rule assumption. Parents can either be known directly or assigned genetically through relationship reconstruction algorithms. In summary, this method holds great promise for barrier assessment in that it is able to provide estimates of both movement rate and directionality without the time lag of traditional CMR techniques. 


\section{Example Applications}

I am unaware of published studies using molecular markers specifically to evaluate movement after barrier removal, but several studies have compared genetic characteristics in isolated versus connected aquatic populations (also see excellent review in Storfer and others, 2010). Wofford and others (2005) was one of the first studies to use genetic approaches to evaluate barrier impacts in fish; they found reduced genetic diversity and increased genetic differentiation in coastal cutthroat trout populations isolated by barriers. Neville and others (2006b, 2009) found similar impacts on Lahontan cutthroat (Oncorhynchus clarkii henshawi) and rainbow trout (Oncorhynchus mykiss), where isolated populations had small effective sizes and reduced allelic richness compared to connected populations. Assignment tests also showed more evidence of movement for connected populations than isolated populations (Neville and others, 2006b). Raeymaekers and others (2008) showed a major effect of barriers on both genetic diversity and inter-population differences in threespine sticklebacks (Gasterosteus acuelatus) using multivariate models to account for natural genetic patterns influenced by watershed position, habitat width, and river distance. They found an immediate loss of 4 percent of genetic diversity over barriers (that is, in comparing samples directly upstream and downstream of the barrier). Cumulatively, barriers caused a 40 percent loss of genetic diversity throughout the entire system (Raeymaekers and others, 2009). Simulations suggested benefits of passage removal could be detected in sticklebacks in two to seven generations as measured by decreased differentiation between populations upstream and downstream of the former barrier sites (Raeymaekers and others, 2009). Simulations by Langduth and others (2010) suggest a longer time-frame ( $<15$ generations) for full erasure of a barrier effect using individual-based Mantel's tests (an isolation by distance method) in a relatively vagile species. This time-lag may be longer than desirable for demonstrating the effectiveness of restoration projects, but well-designed comparative studies should show movement more quickly (that is, where one would hypothesize a decrease in the signatures of isolation compared to appropriate control samples, not necessarily full erasure), and assignment tests (see Manel and others, 2005, 2007) and sibship approaches theoretically could capture movement as soon as it occurs (Yamamoto and others, 2004).

\section{Conclusion}

Although examples of genetic evaluation of passage after crossing structure removal are still lacking, comparative studies, simulations, and theory suggest genetic approaches could provide powerful tools for assessing passage at restoration sites. The efficacy of these measurements may depend on landscape context of the restoration site and the vagility of the species (Hughes, 2007), as well as the life history stage of interest (that is, adults vs. juveniles, or resident vs. migratory); but for most scenarios, one or a combination of genetic approaches could be applied successfully. Finally, genetic approaches provide a highly effective tool for monitoring hybridization with non-native species (see, for example, Fausch and others, 2009; Bennett and others, 2010) after connectivity has been restored. 


\section{Relevance, Strengths, and Limitations of the Four Methods}

In this section, we provide a brief overview of the four methods reviewed in the previous section and evaluate their relevance to three simple questions often associated with evaluating effectiveness of aquatic organism passage and restoration:

- Can individuals move through a road-stream crossing?

- Do road-stream crossings impact populations?

- How do stream-road crossings impact nonnative species?

We also review the major strengths and weaknesses of each method from the perspective of practical applications by field personnel.

\section{Individual Movement}

Description-This method involves tagging or marking of groups or individually identifiable animals from locations with road-stream crossing structures. Individuals are tagged or marked and released. Subsequent site visits are made to remotely track changes in individual locations (for example, PIT tag, radio, or acoustic telemetry) by relocating or recapturing individuals with tags or marks to determine locations and infer movements.

Questions addressed - This method provides direct evidence of individual movement through road-stream crossing structures. The degree of impacts on movement (positive or negative) can be evaluated in more complex comparative study designs, such as comparing the movement of organisms through a road-stream crossing structure to movement in the stream channel above and below the structure; or to movement in a natural stream channel without a structure. It does not directly address population-level impacts. Invasion of nonnative species can be addressed if they are tagged or marked and included in the study.

Strengths-This approach is a simple and direct way to evaluate movement of individuals in relation to road-stream crossing structures and the effectiveness of restoration efforts. It can be implemented by most field personnel, analysis and interpretation of results is straightforward, and it can be applied at single or multiple locations. Turchin (1998) describes potentially useful methods for analyzing movement data.

Limitations-Failure to detect movement can result from various study design limitations, including insufficient numbers of individuals tagged or marked, tag or mark loss, and insufficient effort in tracking, relocation, or recaptures. This method only applies to species that are relatively mobile and to locations with a relatively large number of individuals.

\section{Occupancy Models}

Description - This method involves repeated sampling of locations to estimate the probabilities of detection and presence for different species. This approach also can be extended to estimate probabilities of different abundance categories, rather than presence alone. More complex designs involving more intensive field efforts can be used to evaluate other responses, such as extinction and colonization probabilities. 
Questions addressed-Species presence can be a consequence of individual movement, which can be indirectly inferred with properly designed comparative studies, such as the presence of a species or species before and after passage restoration; or presence at restored versus impaired locations. Population impacts, as indicated by patterns of species presence, or in some cases levels of abundance, or probabilities of extinction and colonization, can be evaluated, depending on the study design.

Strengths - Occupancy models can be applied to common field survey methods, such as underwater observation (that is, snorkeling), electrofishing, or benthic sample surveys. The survey methods can be easily adapted to provide occupancy-based estimates for a wide number of native and nonnative species. Continuing advances in occupancy estimation provide increasing opportunities for estimating a variety of parameters, including detectability, presence, abundance, colonization, and extinction probabilities. MacKenzie and others (2006) describe potentially useful methods for analyzing occupancy data.

Limitations-Study design development and analytical methods required for occupancy estimation are complex and require consultation with a biometrician qualified in the analysis of occupancy data and occupancy models. Applications of occupancy models for estimating presence, the most common application at this time, are not useful when species are relatively uncommon or rare, or for species that are very common or widespread. Estimation of presence and detection probabilities requires sampling at multiple locations, preferably more than 20, so this approach is not easily adapted to evaluations of single or a few sites or projects.

\section{Abundance (Demography)}

Description-This method involves estimation of the abundance or density of individuals relative to the presence of a road-stream crossing structure. Comparisons may involve the abundance or density of individuals upstream or downstream of a structure, and comparison to locations without the influence of a road-stream crossing structure.

Questions addressed - Individual movements are inferred indirectly through formulation of alternative hypotheses and predictions about impacts of movement on abundance (that is, decreased movement or passage results in decreased abundance). Population impacts are directly considered in terms of abundance or density of individuals in relation to road-stream crossing structures. Estimates can include native and nonnative species.

Strengths-Abundance or density is a common management or conservation objective directly addressed by this method and can be applied at single or multiple locations.

Limitations - The roles of specific processes influencing population abundance or density can be difficult to isolate with this approach, and therefore linking patterns to impacts of roadstream crossing structures can be challenging. Abundance or population density can be difficult to quantify in practice, due to unknown or variable capture or sighting probabilities of individuals (for example, Dunham and others, 2009), and this method can only be applied at locations with sufficient numbers of individuals present to allow estimation of abundance.

\section{Molecular Genetic Markers}

Description-This method involves the use of molecular genetic markers to assess patterns of variability within populations, gene flow among populations, and assignment of the origin of individuals. Individuals are captured in the field to provide tissue samples for DNA extraction. Sampling locations are selected to address questions about impacts of road-stream crossing structures and the effectiveness of restoration efforts. 
Questions addressed — Molecular genetic markers can address individual- and population-level impacts of road-stream crossing structures, as well as impacts of or invasion by nonnative species. Individual movements are inferred indirectly by the locations of individuals relative to their assigned origin (but see text box, page 26). If individual locations at the time of sampling do not correspond to the location they are genetically assigned to, movement is inferred. Individual movement also can be determined by identifying locations of siblings relative to one another, or their parents, using similar logic. Population impacts are addressed by relative levels of genetic variability within populations or estimation of the number of reproductive adults using allele frequency data. Gene flow (resulting from individual movement) among populations is indirectly estimated from population allele frequencies. This approach can be applied to native and nonnative species. It also provides unique information on hybridization between species in cases where it occurs naturally or is the result of contact with a closely related nonnative species.

Strengths-Molecular genetic markers can address a wide range of impacts linked to road-stream crossing structures, and also integrate the results of movements over long time spans. Data needed for analyses can be collected with a single field visit and can be used to determine passage at single or multiple locations.

Limitations-Molecular genetic markers, if not already completed, must be identified prior to analysis. The analysis and interpretation of molecular genetic data requires laboratory facilities and analytical methods that typically cannot be implemented by field personnel. Sample processing and data analysis and interpretation should be completed in consultation with experienced and qualified geneticists. Molecular genetic markers can be used only for species and locations with sufficient numbers of individuals available to provide sufficient tissue samples for DNA.

\section{Guidelines for Selecting a Method}

In this section, we provide guidelines for selecting a method for evaluating aquatic organism passage through road-stream crossing structures and the effectiveness of efforts to restore passage. Three important questions need to be addressed when developing a plan for evaluating aquatic organism passage.

\section{What Do We Need to Know?}

An obvious but often overlooked step is clearly defining the objectives of a monitoring effort, including, in the context of this report, specific questions about the impacts of road-stream crossing structures. In general, questions about passage can range from individual movements to population impacts and invasions by nonnative species. Stating the questions clearly is critical because they dictate the methods that are most likely to apply. Often we find a stated objective is something like "to determine the impacts of..." which is not specific to a particular response or affected process. It is important to be as specific as possible, so an appropriate method of monitoring can be identified. Questions about movement are most directly addressed by direct tracking of individual movements or applications of molecular genetic markers that identify origins of individuals. 
The finding that a few individuals can use and move through a crossing structure, however, may not be sufficient in many regulatory settings. Often population impacts are a primary concern. In this case, it may be prudent to consider applications of molecular genetic markers that identify patterns of genetic variability within and among populations, as well as occupancy models that estimate the probability of presence, colonization, or levels of abundance. Abundance alone may not be a very useful indicator of population responses, because it may be affected by various other factors that are difficult to control and unrelated to impacts of the structure itself. Questions about nonnative species invasion can be addressed by tracking individual movements directly or with molecular genetic markers and occupancy models. Genetic approaches also can diagnose problems with interspecific hybridization, where possible, between native and nonnative species.

Lindenmayer and Likens (2009, p. 482) state that "many long-term research and monitoring programs are either ineffective or fail completely owing to poor planning and/or lack of focus.” By adequately answering the following questions before a project is implemented and sampling is begun, the success of the sampling and monitoring effort will be greatly enhanced.

\section{Pre-Implementation Questions}

1. What do we want to learn (condition or change of interest) and what are the key questions we need to ask?

2. Have we clearly defined our project goal and objectives?

3. Do we have or can we develop a conceptual model of what we want to learn?

4. Have we selected suitable and meaningful variables (indicators) for detecting our condition(s) or change(s) of interest?

5. Are our study and sampling designs appropriate and capable of detecting and quantifying our condition(s) or change(s) of interest; do they yield adequate statistical power?

6. Are the spatial and temporal frames of our study and sampling designs adequate for detecting our condition(s) or change(s) of interest?

7. How will we analyze and use the information we collect?

8. How will we determine if our research or monitoring efforts are successful?

For additional information see the following useful references: Olsen and others (1999), Urquhart and Kincaid (1999), McDonald (2003), Field and others (2007), Fancy and others (2009), Lindenmayer and Likens (2009), and Thompson and others (2011). 


\section{Can We Do This Ourselves?}

Monitoring programs typically operate on limited budgets. For field personnel with time available, the least expensive option is to conduct monitoring without outside assistance. Budgets aside, the degree to which this is possible depends, in part, on the intensity and complexity of field operations, data analysis, and interpretation. On a relative scale among the methods considered here, individual movement and abundance are most feasible with respect to these considerations. Sampling for genetic analyses is relatively straightforward in the field, provided that sampling is designed to be compatible with the questions to be addressed. Analysis of genetic variability in the laboratory and the statistical analysis of this variability generally requires outside assistance. Similarly, for occupancy modeling, data are straightforward to collect in the field, but analyses can be technically challenging and best conducted with outside assistance. Here are some basic questions to consider:

1. Overarching question: Do we have enough money and personnel to meet our monitoring goal and objectives or do we need to collaborate with other agencies or entities?

2. What is the overall estimated cost for successfully completing sampling and meeting our monitoring goal and objectives?

3. What are the personnel requirements - number and cost?

4. What are the logistical requirements - intensity and complexity (for example, site locations; travel; lodging; personnel supplies and sustenance)?

5. What are the supplies and equipment requirements - types and cost (for example, do we need to purchase specialized sampling and monitoring equipment; are the costs of specialized equipment expensive)?

\section{What Situation Am I Dealing With?}

The feasibility of using one or more of the monitoring methods discussed in this report is strongly dictated by the situation in question. This includes the likelihood that a given species is present upstream or downstream of a road-stream crossing structure, the general expected pattern of abundance of a species of interest (table 5), and the level of passage impairment caused by the structure. 
Table 5. Classification of feasible alternative methods for monitoring biotic responses to the presence of road-stream crossing structures in different scenarios representing variability in species presence and abundance.

[Filled cells represent cases where a particular monitoring approach is feasible, based only on these criteria. Darkest shading indicates that the use of the approach is most likely feasible, lighter shading indicates potential feasibility, and unshaded cells indicate that use of approach probably is not feasible]

\begin{tabular}{|l|c|c|c|c|c|}
\hline Species presence: & \multicolumn{2}{|l|}{ Prevalence: Not present everywhere } & \multicolumn{2}{l|}{ Prevalence: Present everywhere } \\
\hline Abundance: & Low & Moderate & High & $\begin{array}{c}\text { Low } \\
\text { somewhere }\end{array}$ & $\begin{array}{c}\text { Abundant } \\
\text { everywhere }\end{array}$ \\
\hline Individual telemetry & & \multicolumn{3}{|l}{} \\
\hline Occupancy modeling & & & & & \\
\hline Mass marking & & & & & \\
\hline Abundance & & & & & \\
\hline Genetic assignments & & & & & \\
\hline Population genetics & & & & & \\
\hline
\end{tabular}

A second consideration is the number of road-stream crossing structures to be evaluated. It is often the case that only a single structure and crossing may be of interest; in others, a broader or more programmatic sample of structures and crossings may be of interest. In the context of these considerations it is possible at one or multiple sites to monitor individual movement and abundance and to utilize molecular genetic methods that identify sources of individuals. Occupancy modeling, however, is best applied to a sample of multiple structures and crossings, rather than at just a single structure and crossing, with the possible exception of cases where repeated sampling over many years at a given location is desired. Table 6 presents relatively simply the basic utility of each method based on three considerations: number of sites, location of species, and focus of method. 
Table 6. Summary of the utility of each method relative to three basic considerations: (1) the number of road-stream crossing structures of interest; (2) presence of the species of interest relative to the crossing(s); and (3) general focus of the method.

\begin{tabular}{|c|c|c|}
\hline Method & Consideration & Utility \\
\hline \multirow[t]{3}{*}{ Individual Movement } & Number of sites & Most feasible at single to a few $(\leq 20)$ sites \\
\hline & Species presence & $\begin{array}{l}\text { Must be present upstream and downstream of } \\
\text { crossing }\end{array}$ \\
\hline & Focus of method & $\begin{array}{l}\text { Movement of individuals of single or multiple } \\
\text { species (individually or mass-marked) }\end{array}$ \\
\hline \multirow[t]{3}{*}{ Occupancy Models } & Number of sites & $\begin{array}{l}\text { Multiple ( } \geq 20) \text { sites; less often multiple visits at a } \\
\text { single site }\end{array}$ \\
\hline & Species presence & $\begin{array}{l}\text { Must be variable (table 5) and can be evaluated } \\
\text { upstream or downstream of crossings - most often } \\
\text { upstream of crossings }\end{array}$ \\
\hline & Focus of method & $\begin{array}{l}\text { Estimates probability of presence in relation to } \\
\text { site characteristics (for example, presence } \\
\text { upstream of a crossing) }\end{array}$ \\
\hline \multirow[t]{3}{*}{ Abundance (Demography) } & Number of sites & Useful at single and multiple sites \\
\hline & Species presence & Upstream or downstream of crossings \\
\hline & Focus of method & $\begin{array}{l}\text { Useful for determining and assessing patterns of } \\
\text { abundance and population density to compare } \\
\text { sites upstream and downstream of crossings in a } \\
\text { single stream or compare sites in streams with and } \\
\text { without crossings }\end{array}$ \\
\hline \multirow[t]{3}{*}{ Molecular Genetic Markers } & Number of sites & Useful at single and multiple sites \\
\hline & Species presence & All locations \\
\hline & Focus of method & $\begin{array}{l}\text { Useful for quantifying patterns of characteristics } \\
\text { of populations indicative of gene flow and local } \\
\text { population size, or under appropriate } \\
\text { circumstances, tracking of individuals (see p. 36). }\end{array}$ \\
\hline
\end{tabular}




\section{Study and Monitoring Design Considerations}

Road-stream crossings encompass a diverse range of conditions. This provides an opportunity to study how these conditions influence aquatic organism passage, but also poses various challenges in selecting an appropriate monitoring method and design. In this section, we address key considerations when designing monitoring efforts to evaluate aquatic organism passage and passage restoration through structures at road-stream crossings. Ideally, we would design our monitoring program that could: (1) collect data for assessing aquatic organism passage through a road-stream crossing prior to replacement of the structure; and (2) compare that assessment to conditions determined after structure replacement. Simple before and after comparisons can be made on a site-by-site basis, but inferences are more powerful when multiple sites are assessed. An ideal approach is a monitoring design with two primary elements-(1) impact and reference sites; and (2) before and after impact sampling and evaluation.

In practice, opportunities to implement the ideal monitoring design described above typically are limited, and if possible only applicable to a handful of locations. More often it is the case that effectiveness monitoring of restoration occurs well after the restoration itself is implemented. Consequently, we assume that most evaluations of passage effectiveness will involve retrospective comparisons of sites with and without crossings. This approach deviates considerably from the ideal, but there are several steps that can be taken to design retrospective studies of effectiveness to provide robust and relevant results. These steps are the focus of the remainder of this section.

The first step in designing an evaluation of passage effectiveness is to consider where passage structures are located within a given stream network. The branching pattern of a stream network can have profound influences on the distributions of different species (for example, Sheldon, 1968; Hynes, 1970; Vannote and others, 1980) and geomorphic processes (Frissell and others, 1986; Benda and others, 2004). Accordingly, the location of a crossing within a stream network can influence how it impacts physical and biotic processes. The simplest case is a crossing located on a stream with a relatively long $(\geq 0.50 \mathrm{~km})$ and homogeneous length of channel upstream and downstream of the crossing. In this situation, it is possible to conduct monitoring to compare biotic conditions and responses upstream and downstream of the crossing, and to determine if conditions and responses upstream of the crossing resemble those downstream. Often, however, crossings are located on smaller tributaries that occur just upstream of confluences with larger rivers, leaving only a short section of channel below a crossing upstream of the confluence. This is common because many road systems parallel larger streams, crossing many smaller tributaries near their confluences. In these cases, upstream and downstream comparisons are not possible, and a separate reference site or sites may need to be used as part of the design.

When a separate reference site is used for comparison of responses and conditions with a crossing site, the fundamental assumption is that the reference and crossing sites have similar potential physical conditions and the same potential species present. If this assumption is valid, differences between a reference and crossing site are attributable to the impact of the structure at the crossing. If for some reason, however, it is not possible to establish one or more reference sites, a reference condition (or conditions) can be identified and defined against which the level of passage impairment or passage restoration effectiveness at an impact site can be compared. Guidelines on establishing reference conditions are shown in Stoddard and others (2006). 
Rarely is it the case that perfectly comparable sites are available for monitoring the impairment of aquatic organism passage at road-stream crossings or the effectiveness of efforts to restore passage. Among the many site characteristics to consider, stream size is likely the most important influence on comparability of sites within a given watershed. For example, a recent study of population genetic impacts of culvert barriers on rainbow trout (Oncorhynchus mykiss) in Idaho streams found that impacts were most evident for small streams, and became less apparent as streams increased in size (Neville and others, 2009). Similar results were found in a study of the impacts of small dams on persistence of white-spotted charr (Salvelinus leucomaenis) in Japan (Morita and Yamamoto, 2002). In that study, persistence of local populations (as indicated by presence) was greater for larger streams. Thus, it is important for a variety of reasons (Dunham and others, 2003) to consider stream size as a factor that can modify the response of aquatic organisms to changes in conditions influencing passage. It also is critical to ensure that the effect of passage is not confounded with factors like stream size. For example, if one were comparing crossings on large streams to reference sites located on streams that generally were smaller or larger, it would be impossible to attribute differences between these streams to the independent effects of the crossings, stream size, or both acting together. If stream sizes were not different in these comparisons, stream size could be eliminated as a likely explanation for differences among sites.

Other common factors that influence the expected impacts of crossings on biota include the landscape context of the crossing site, design and condition of the crossing structure, physical-hydrological-biological characteristics of the stream at the crossing, and time since crossing conditions have changed substantially (for example, time since restoration or impairment). Obviously, the life history and movement characteristics of species of concern also will impact study outcomes. The characteristics of crossings that potentially impact aquatic organisms are described extensively on the U.S. Forest Service FishXing website (www.stream.fs.fed.us/fishxing/) where a number of useful background and guidance documents are digitally available.

Landscape context refers to the setting in which a particular location is embedded within a landscape. The important concept here is that conditions within the broader landscape exert control on conditions that are realized within any particular location or site (Peterson and Dunham, 2010). For streams, we consider context to represent the suite of vegetative, climatic, and geomorphic conditions that exert higher level control on processes that influence both physical and biotic conditions at any given location and at any given time (Frissell and others, 1986; Montgomery, 1999; Benda and others, 2004). Examples of attempts to broadly quantify landscape context include a national classification of hydrological landscapes (Wolock and others, 2004) and land-cover based indices of hydrological alteration (Falcone and others, 2010).

Readily available spatial data, such as elevation, slope, and drainage area that help describe the landscape context of a stream, can be useful to select sites that are comparable for monitoring. These characteristics also may be used as potential explanatory variables, in addition to passage conditions, for quantifying biotic responses at crossings and to crossing structures (for example, Neville and others, 2009). An alternative to this would be to quantify local physical and biotic stream conditions in the field prior to selecting sites, but given the high cost of this alternative, we suspect that an approach based on existing spatial data will be most generally cost-effective and efficient. 
Time is a critical factor affecting biotic responses to conditions at crossings. It can take a species one or more generations to respond to changes in connectivity or isolation. Similarly, lack of an immediate response does not mean a species will not respond in the future. A good example would be a potential delay in colonization of a newly accessible site by a rare species. In this case, the probability of a sufficient number of individuals dispersing to and establishing a local population may be relatively low because the species is rare to begin with. This also may be the case for invasion by nonnative species. Morita and Yamamoto (2002) found that time since isolation was a critical factor influencing persistence of white-spotted charr upstream of passage barriers, and populations isolated for longer time periods were more likely to suffer local extirpation.

It also is important to understand the history of events that could have influenced aquatic organism passage at any given site. This may include information on when a crossing structure (for example, culvert or diversion dam) was installed, the number of times it was breached or washed out, or when passage conditions were restored. Other historical factors that may be important include game fish stocking records, histories of chemical treatments (for example, antimycin or rotenone), natural or human-caused land or water disturbances, instream habitat restoration, changes in game fish harvest regulations, and the history of when or if passage conditions within a stream network were studied.

\section{References Cited}

Adams, S.B., Schmetterling, D.A., and Young, M.K., 2005, Instream movement of boreal toads (Bufo boreas boreas): Herpetological Review, v. 36, p. 27-33.

Anderson, L., and Bryant, M., 1980, Fish passage at road crossings: An annotated bibliography: USDA Forest Service, Pacific Northwest Forest and Range Experiment Station GTR PNW117, Portland, OR, 10 p.

Ashton Jr., R.E., 1975, A study of movement, home range, and winter behavior of Desmognathus fuscus (Rafinesque): Journal of Herpetology, v. 91, p. 85-91.

Avise, J.C., 2004, Molecular markers, natural history, and evolution, Second Edition: Sinauer Associates, Sunderland, Mass., 684 p.

Baker, R.D., Maxwell, R.S., Treat, V.H., and Dethloff, H.C., 1988, Timeless heritage: A history of the Forest Service in the southwest: USDA Forest Service FS-409, 208 p.

Benda, L., Miller, D., Dunne, T., Poff, L., Reeves, G., Pollock, M., and Pess, G., 2004, Network dynamics hypothesis-Spatial and temporal organization of physical heterogeneity in rivers: Bioscience, v. 54, p. 413-427.

Bennett, S.N., Olson, J.R., Kershner, J.L., and Corbett, P., 2010, Propagule pressure and stream characteristics influence introgression: cutthroat and rainbow trout in British Columbia: Ecological Applications, v. 20, p. 263-277.

Bilton, D.T., Freeland, J.R., and Okamura, B., 2001, Dispersal in freshwater invertebrates: Annual Review of Ecology, Evolution, and Systematics, v. 32, p. 159-181.

Bird, G.A., and Hynes, H.B.N., 1981, Movement of immature aquatic insects in a lotic habitat: Hydrobiologia, v. 77, p. 103-112.

Bisson, P.A., Nielsen, J.L., Palmason, R.A., and Grove, L.E., 1982, A system of naming habitats in small streams, with examples of habitat utilization by salmonids during low streamflow, in Armentrout, N.B., ed., Acquisition and utilization of aquatic habitat: Western Division of the American Fisheries Society, Portland, Oreg., p. 62-73. 
Blank, M., Cahoon, J., Burford, D., McMahon, T., and Stein, O., 2006, Studies of fish passage through culverts in Montana, in Irwin, C.L, Garrett, P., and McDermott, K.P., eds., Proceedings of the 2005 International Conference on Ecology and Transportation: Center for Transportation and the Environment, North Carolina State University, Raleigh, N.C., p. 20-29. Bouska, W.W., and Paukert, C.P., 2010, Road crossing designs and their impact on fish assemblages of Great Plains streams: Transactions of the American Fisheries Society, v. 139, p. 214-222.

Bubb, D.H., Lucas, M.C., and Thom, T.J., 2002, Winter movements and activity of signal crayfish Pacifastacus leniusculus in an upland river, determined by radio telemetry: Hydrobiologia, v. 483, p. 111-119.

Bubb, D.H., Thom, T.J., and Lucas, M.C., 2004, Movement and dispersal of the invasive signal crayfish Pacifastacus leniusculus in upland rivers: Freshwater Biology, v. 49, p. 357-368.

Bubb, D.H., Thom, T.J., and Lucas, M.C., 2005, The within-catchment invasion of the nonindigenous signal crayfish Pacifastacus leniusculus (Dana) in upland rivers: Bulletin Francais de la Peche et de la Pisciculture, v. 376-377, p. 665-673.

Bubb, D.H., Thom, T.J., and Lucas, M.C., 2006, Movement patterns of the invasive signal crayfish determined by PIT telemetry: Canadian Journal of Zoology, v. 84, p. 1202-1209.

Buck, C.J., 1936, Forest roads or forest fires? accessed March 26, 2012, at http://www.foresthistory.org/ASPNET/Policy/Fire/Forest_roads.aspx.

Burford, D.D., McMahon, T.E., Cahoon, J.E., and Blank, M., 2009, Assessment of trout passage through culverts in a large Montana drainage during summer low flow: North American Journal of Fisheries Management, v. 29, p. 739-752.

Burkholder, L.L., and Diller, L.V., 2007, Life history of postmetamorphic coastal tailed frogs (Ascaphus truei) in northwestern California: Journal of Herpetology, v. 41, p. 251-262.

Cahoon, J.E., McMahon, T., Solcz, A., Blank, M., and Stein, O., 2007, Fish passage in Montana culverts: Phase II - passage goals: Final Report prepared for the State of Montana Department of Transportation in cooperation with the U.S. Department of Transportation, Federal Highway Administration, Montana State University, Bozeman, MT, 64 p.

Campbell-Grant, E.H., Nichols, J.D., Lowe, W.H., and Fagan, W.F., 2010, Use of multiple dispersal pathways facilitates amphibian persistence in stream networks: Proceedings of the National Academy of Sciences, v. 107, p. 6936-6940.

Carpenter, C.C., 1954, A study of amphibian movement in the Jackson Hole Wildlife Park: Copeia, p. 197-200.

Castric, V., Bonney, F., and Bernatchez, L., 2001, Landscape structure and hierarchical genetic diversity in the brook charr, Salvelinus fontinalis: Evolution, v. 55, p. 1016-1028.

Clarkin, K., Connor, A., Furniss, M.J., Gubernick, B., Love, M., Moynan, K., and Wilson Musser, S., 2005, National Inventory and Assessment Procedure-For identifying barriers to aquatic organism passage at road-stream crossings: USDA Forest Service, National Technology and Development Program, 7700-Transportation Mgmt, San Dimas, CA, 61 p.

Coffman, J.S., 2005, Evaluation of a predictive model for upstream fish passage through culverts[thesis]: Harrisonburg, Va., James Madison University, 111 p.

Colyer, W.T., Kershner, J.L., and Hilderbrand, R.H., 2005, Movements of fluvial Bonneville cutthroat trout in the Thomas Fork of the Bear River, Idaho-Wyoming: North American Journal of Fisheries Management, v. 25, p. 954-963.

Conrad, D.E., 1997, The land we cared for...A history of the Forest Service's Eastern Region: USDA Forest Service, Region 9, Milwaukee, WI, 312 p. 
Copstead, R.L., Moore, K., Ledwith, T., and Furniss, M., 1998, An annotated bibliography: San Dimas Technology and Development Center, San Dimas, CA, 154 p.

Cosentino, B.J., Lowe, W.H., and Likens, G.E, 2009, Demography and movement of the northern spring salamander in four New Hampshire headwater streams: Verhandlungen des Internationalen Verein Limnologie, v. 30, p. 677-680.

Daugherty, C.H., and Sheldon, A.L., 1982, Age-specific movement patterns of the frog Ascaphus truei: Herpetologica, v. 38, p. 468-474.

Dryden, R.L., and Jessop, C.S., 1974, Impact analysis of the Dempster Highway culvert on the physical environment and fish resources of Frog Creek, Resource Management Branch, Central Region: Environment Canada, Fisheries and Marine Service, CEN/T-74-5, 59 p. Duarte, C.M., Agusti, S., and Peters, H., 1987, An upper limit to the abundance of aquatic Organisms: Oecologia, v. 74, p. 272-276.

Dunham, J.B., Rieman, B.E., and Peterson, J.T., 2002a, Patch-based models of species

occurrence: lessons from salmonid fishes in streams, in Scott, J.M., Heglund, P.J., Morrison, M., Raphael, M., Haufler, J., and Wall, B., eds., Predicting species occurrences: Issues of scale and accuracy: Island Press, Covelo, CA, p. 327-334.

Dunham, J.B., Cade, B.S., and Terrell, J.W., 2002b, Influences of spatial and temporal variation on fish-habitat relationships defined by regression quantiles: Transactions of the American Fisheries Society, v. 131, p. 86-98.

Dunham, J.B., Young, M.K., Gresswell, R.E., and Rieman, B.E., 2003, Effects of fire on fish populations: Landscape perspectives on persistence of native fishes and nonnative fish invasions: Forest Ecology and Management, v. 178, p. 183-196.

Dunham, J.B., Rosenberger, A.E., Thurow, R.F., Dolloff, A.E., and Howell, P.J., 2009, Coldwater fishes in wadeable streams, in Bonar, S., Hubert, W., and Willis, D., eds., Standard methods for sampling North American freshwater fishes: American Fisheries Society, Bethesda, MD, p. 119-138.

Dunning, J.B., Danielson, J.B., and Pulliam, H.R., 1992, Ecological processes that affect populations in complex landscapes: Oikos, v. 65, p. 169-175.

Ebersole, J.L., Wigington Jr., P.J., Baker, J.P., Cairns, M.A., Church, M.R., Hansen, B.P., Miller, B.A., Compton, J.E,. and Leibowitz, S.G., 2006, Juvenile coho salmon growth and survival across stream network seasonal habitats: Transactions of the American Fisheries Society, v. 135, p. 1681-1697.

Ebert, T.A., 1998, Plant and animal populations: Methods in demography: Academic Press, San Diego, CA and London, UK, 312 p.

Evans, W.A., and Johnson, F.B., 1972, Fish migration and fish passage: A practical guide to solving fish passage problems: USDA Forest Service, Region 5, 41 p.

Falcone, J.A., Carlisle, D.M., Wolock, D.M., and Meador, M.R., 2010, GAGES: A stream gage database for evaluating natural and altered flow conditions in the conterminous United States: Ecology, v. 91, p. 621.

Fancy, S.G., Gross, J.E., and Carter, S.L., 2009, Monitoring the condition of natural resources in US national parks: Environmental Monitoring and Assessment, v. 151, p. 161-174.

Fausch, K.D., and Young, M.K., 1995, Evolutionarily significant units and movement of resident stream fishes: a cautionary tale: American Fisheries Society Symposium, v. 17, p. 360-370. 
Fausch, K.D., Hawkes, C.L., and Parsons, M.G., 1988, Models that predict standing crop of stream fish from habitat variables-1950-85: General Technical Report PNW-GTR-213, U.S. Department of Agriculture, Forest Service, Pacific Northwest Research Station, Portland, OR, $52 \mathrm{p}$.

Fausch, K.D., Rieman, B.E., Young, M.K., and Dunham, J.B., 2006, Strategies for conserving native salmonid populations at risk from nonnative fish invasions-Tradeoffs in using barriers to upstream movement: General Technical Report RMRS-GTR-174, U.S. Department of Agriculture, Forest Service, Rocky Mountain Research Station, Fort Collins, CO, 44 p.

Fausch, K.D., Torgerson, C.E., Baxter, C.V., and Li, H.W., 2002, Landscapes to riverscapes: Bridging the gap between research and conservation of stream fishes: BioScience, v. 52, p. 483-498.

Fausch, K.D., Rieman, B.E., Dunham, J.B., Young, M.K., and Peterson, D.P., 2009, Invasion versus isolation-Trade-offs in managing native salmonids with barriers to upstream movement: Conservation Biology, v. 23, p. 859-870.

Field, S.A., O’Connor, P.J., Tyre, A.J., and Possingham, H.P., 2007, Making monitoring meaningful: Austral Ecology, v. 32, p. 485-491.

Frissell, C.A., Liss, W.J., Warren, C.E., and Hurley, M.D., 1986, A hierarchical framework for stream habitat classification-Viewing streams in a watershed context: Environmental Management, v. 10, p. 199-214.

Furniss, M., Love, M., Firor, S., Moynan, K., Llanos, A., Guntle, J., and Gubernick, R., 2008, FishXing-Version 3.0: U.S. Forest Service, San Dimas Technology and Development Center, San Dimas, CA. (Also available at www.stream.fs.fed.us/fishxing.)

General Accounting Office, 2001, Land Management Agencies-Restoring fish passage through culverts on Forest Service and BLM lands in Oregon and Washington could take decades: Report to the ranking minority member, Subcommittee on Interior and related agencies, Committee on Appropriations, House of Representatives, GAO-02-136, 29 p. (Also availableat http://www.gao.gov/new.items/d02136.pdf.)

Gavin, T.A., 1991, Why ask "why"—The importance of evolutionary biology in wildlife science: The Journal of Wildlife Management, v. 55, p.760-766.

Gebhards, S., and Fisher, J., 1972, Fish passage and culvert installations: Idaho Fish and Game Department, $12 \mathrm{p}$.

Gherardi, F., Barbaresi, S., and Salvi, G., 2000, Spatial and temporal patterns of the movement of Procambarus clarkii, an invasive crayfish: Aquatic Sciences, v. 62, p. 179-193.

Gibbs, J.P., 1998, Amphibian movements in response to forest edges, roads, and streambeds in southern New England: Journal of Wildlife Management, v. 62, p. 584-589.

Gotelli, N.J., 2008., A primer of ecology, 4th edition: Sinauer Associates, Inc., Sunderland, MA, $290 \mathrm{p}$.

Gowan, C., Young, M.K., Fausch, K.D., and Riley, S.C., 1994, Restricted paradigm in resident stream salmonids-A paradigm lost?: Canadian Journal of Fisheries and Aquatic Sciences, v. 51, p. 2,626-2,637.

Grant, J.W.A., and Noakes, D.L.G., 1987, Movers and stayers-Foraging tactics of young-ofthe-year brook charr, Salvelinus fontinalis: Journal of Animal Ecology, v. 56, p. 1,001-1,013.

Grant, J.W.A., Steingrímsson, S.Ó., Keeley, E.R., and Cunjak, R.A., 1998, Implications of territory size for the measurement and prediction of salmonid abundance in streams: Canadian Journal of Fisheries and Aquatic Sciences, v. 55, supp. 1, p.181-190. 
Gregory, S., Klingeman, P.K., McEnroe, J., and Wyrick, J., 2004, Final Report—Fish passage through retrofitted culverts: Fish Passage Research Project 99-626, Oregon Department of Transportation, Federal Highway Administration, Salem, OR, 76 p.

Griswold, K.E., 1996, Genetic and meristic relationships of coastal cutthroat trout

(Oncorhynchus clarkii clarkii) residing above and below barriers in two coastal basins: Oregon State University, Corvallis, OR, thesis, 83 p.

Gubernick, B., Clarkin, K., and Furniss, M.J., 2003, Site assessment and geomorphic considerations in stream simulation culvert design, in Irwin, C.L., Garrett, P., and McDermott, K.P., eds., International Conference on Ecology and Transportation, Raleigh, North Carolina State University, 2003, Proceedings: Raleigh, North Carolina State University, Center for Transportation and the Environment, p. 30-41.

Guy, T.J., Gresswell, R.E., and Banks, M.A., 2008, Landscape-scale evaluation of genetic structure among barrier-isolated populations of coastal cutthroat trout, Oncorhynchus clarkii clarkii: Canadian Journal of Fisheries and Aquatic Sciences, v. 65, p. 1749-1762.

Hayes, M.P., Quinn, T., Dugger, D.J., Hicks, T.L., Melchiors, M.A., and Runde, D.E., 2006, Dispersion of coastal tailed frog (Ascaphus truei)—An hypothesis relating occurrence of frogs in non-fish bearing headwater basins to their seasonal movements: Journal of Herpetology, v. 40, p. 531-543.

Hilderbrand, R.H., and Kershner, J.L., 2000, Conserving inland cutthroat trout in small streams - How much stream is enough?: North American Journal of Fisheries Management, v. 20, p. 513-520.

Hovingh, P., 2004, Intermountain freshwater mollusks, USA (Margaritifera, Anodonta, Gonidea, Valvata, Ferrissia) — Geography, conservation, and fish management implications: Monographs of the Western North American Naturalist, v. 2, p.109-135.

Hudson, J.M., Luzier, C., Cook, J.R., Silver, G., and Johnson, J., 2009, Tryon Creek Restoration Monitoring Project: FY2005-2007 Progress Report: U.S. Fish and Wildlife Service, Columbia River Fisheries Program Office, Vancouver, WA, 10 p.

Hughes, J.M., 2007, Constraints on recovery-Using molecular methods to study connectivity of aquatic biota in rivers and streams: Freshwater Biology, v. 52, p. 616-631.

Hynes, H.B.N., 1970, The ecology of running waters: University of Toronto Press, 555 p.

Jackson, S.D., 2003, Ecological considerations in the design of river and stream crossings, in Irwin, C.L., Garrett, P., and McDermott, K.P., eds., in International Conference on Ecology and Transportation, Raleigh, North Carolina State University, 2003, Proceedings: Raleigh, North Carolina State University, Center for Transportation and the Environment, p. 20-29.

Katano, O., Nakamura, T., Abe, S., Yamamoto, S., and Baba, Y., 2006, Comparison of fish communities between above- and below-dam sections of small streams-barrier effect to diadromous fishes: Journal of fish Biology, v. 68, p.767-782.

Kay, A.R., and Lewis, R.B., 1970, Passsage of anadromous fish thru highway drainage structures: State of California, Department of Public Works, Division of Highways, District 01, Hydraulics Section, 629110, 30 p.

Kay, D.W.,1989, Movements and homing in the canyon tree frog (Hyla cadaverina): Southwestern Naturalist, v. 34, p. 293-295.

Kemp, P.S., and O’Hanley, J.R., 2010, Procedures for evaluating and prioritizing the removal of fish passage barriers-A synthesis: Fisheries Management and Ecology, v. 17, p. 297-322. 
Kerby, J.L., Riley, S.P.D., Kats, L.B., and Wilson, P., 2005, Barriers and flow as limiting factors in the spread of an invasive crayfish (Procambarus clarkii) in southern California streams:

Biological Conservation, v. 126, p. 402-409.

Khan, B., and Colbo, M.H., 2008, The impact of physical disturbance on stream communitiesLessons from road culverts: Hydrobiologia, v. 600, p. 229-235.

Knapp, R.A., Matthews, K.R., Preisler, H.K., and Jellison, R., 2003, Developing probabilistic models to predict amphibian site occupancy in a patchy landscape: Ecological Applications, v. 13, p.1,069-1,082.

Kruse, C.G., Hubert, W.A., and Rahel, F.J., 1998, Single-pass electrofishing predicts trout abundance in mountain streams with sparse habitat: North American Journal of Fisheries Management, v. 18, p. 940-946.

Kruse, C.G., Hubert, W.A., and Rahel, F.J., 2001, An assessment of headwater isolation as a conservation strategy for cutthroat trout in the Absaroka Mountains of Wyoming: Northwest Science, v. 75, p. 1-11.

Lancaster, J., 1999, Small-scale movements of lotic macroinvertebrates with variations in flow: Freshwater Biology, v. 41, p. 605-619.

Lancaster, J., 2008, Movement and dispersion of insects in stream channels-What role does flow play?, in Lancaster, J., and Briers, R.A., eds., Aquatic insects—Challenges to populations: Oxfordshire, UK, CAB International, p. 139-157.

Lang, M., Love, M., and Trush, W., 2004, Improving stream crossings for fish passage: Final Report, National Marine Fisheries Service Contract No. 50ABNF800082, Humboldt State University Foundation, Arcata, CA, 128 p.

Langduth, E.L., Cushman, S.A., Schwartz, M.K., McKelvey, K.S., Murphy, M.A., and Luikart, G., 2010, Quantifying the lag time to detect barriers in landscape genetics: Molecular Ecology v. 19, p. 4,179-4,191.

Lee, E.T., and Wang, J.W., 2003, Statistical methods for survival data analysis, (3d ed): New York, John Wiley and Sons, 534 p.

Lindenmayer, D.B., and Likens, G.E., 2009, Adaptive monitoring-A new paradigm for longterm research and monitoring: Trends in Ecology and Evolution, v. 24, p. 482-486.

Lowe, W.H., 2003, Linking dispersal to local population dynamics-A case study using a headwater salamander system: Ecology, v. 84, p. 2,145-2,154.

Lowe, W.H., and Bolger, D.T., 2002, Local and landscape-scale predictors of salamander abundance in New Hampshire headwater streams: Conservation Biology, v. 16, p.183-193.

Lowman, B., 1974, Investigation of fish passage problems through culverts: USDA Forest Service, Equipment Development Center, 2427, Missoula, MT, 17 p.

Lydeard, C., and others, 2004, The global decline of nonmarine mollusks: BioScience, v. 54, p. 321-330.

MacKenzie D.I., and Royle, J.A., 2005, Designing efficient occupancy studies-General advice and tips on allocation of survey effort: Journal of Applied Ecology, v. 42, p. 1,105-1,114.

MacKenzie, D.I., Nichols, J.D., Hines, J.E., Knutson, M.G., and Franklin, A.D., 2003, Estimating site occupancy, colonization and local extinction when a species is detected imperfectly: Ecology, v. 84, p. 2,200-2,207.

MacKenzie, D.I., Nichols, J.D., Lachman, G.B., Droege, S., Royle, J.A., and Langtimm, C.A., 2002, Estimating site occupancy rates when detection probabilities are less than one: Ecology, v. 83, p. 2,248-2,255. 
MacKenzie, D.I., Nichols, J.D., Royle, J.A. Pollock, K.H., Bailey, L.L., and Hines, J.E., 2006, Occupancy estimation and modeling: Boston, Academic Press, 344 p.

Malmqvist, B., 2002, Aquatic invertebrates in riverine landscapes: Freshwater Biology, v. 47, p. 679-694.

Manel, S., Gaggiotti, O.E., and Waples, R.S., 2005, Assignment methods-Matching biological questions with appropriate techniques: Trends in Ecology and Evolution, v. 20, p.136-142.

Manel, S., Berthoud, F., Bellemain, E., Gaudeul, M., Luikart, G., Swensen, J.E., Waits, L.P., Taberlet, P., and Consortium, I., 2007, A new individual-based spatial approach for identifying genetic discontinuities in natural populations: Molecular Ecology, v. 16, v. 2,031-2,043.

Martof, B., 1953, Home range and movements of the green frog, Rana clamitans: Ecology, v. 34, p. 529-543.

Mastran, S.S., and Lowerre, N., 1983, Mountaineers and rangers-A history of federal forest management in the southern Appalachians 1900-81: Washington, DC, USDA Forest Service FS-380, 191 p.

Matsuda, B.M., and Richardson, J.S., 2005, Movement patterns and relative abundance of coastal tailed frogs in clearcuts and mature forest stands: Canadian Journal of Forest Research, v. 35, p. 1,131-1,138.

McClellan, T., 1971, Fish passage through highway culverts: Portland, OR, U.S. Department of Transportation, Federal Highway Administration, 800332, 223 p.

McDonald, T.L., 2003, Review of environmental monitoring methods-Survey designs:

Environmental Monitoring and Assessment, v. 85, p. 277-292.

McKinley, W.R., and Webb, R.D., 1956, A proposed correction of migratory fish problems at box culverts: Washington Department of Fisheries, Fisheries Research Papers v. 1, p. 33-45.

Merkle, E.L., 1969, Home range of crayfish Orconectes juvenalis: American Midland Naturalist v. 81, p. 228-235.

Mock, K.E., Box, J.C., Chong, J.P., Howard, J.K., Nez, D.A., Wolf, D., Gardner, R.S., 2010, Genetic structuring in the freshwater mussel Anodonta corresponds with major hydrologic basins in the western United States: Molecular Ecology, v. 19, no. 3, p. 1-23.

Montgomery, D.R., 1999, Process domains and the river continuum: Journal of the American Water Resources Association, v. 35, p. 397-410.

Moore, K., Furniss, M., Firor, S., and Love, M., 1999, Fish passage through culverts-An annotated bibliography: Eureka, CA, Six Rivers National Forest Watershed Interactions Team, $36 \mathrm{p}$.

Morita, K., and Yamamoto, S., 2002, Effects of habitat fragmentation by damming on the persistence of stream-dwelling charr populations: Conservation Biology, v. 16, p.1,318-1,323.

Morita, K., Morita, S. H., and Yamamoto, S., 2009, Effects of habitat fragmentation by damming on salmonid fishes-Lessons from white-spotted charr in Japan: Ecological Research, v.24, p. 711-722.

Murray, D.L., and Fuller, M.R., 2000, A critical review of the effects of marking on the biology of vertebrates, in Boitani, L., and Fuller, T.K., eds, Research techniques in animal ecology, Controversies and consequences: New York, Columbia University Press, p. 15-64.

National Marine Fisheries Service, 2001, Guidelines for salmonid passage at stream crossings, National Oceanic and Atmospheric Administration: Department of Commerce, and National Marine Fisheries Service, Southwest Region, 14 p. (Also available http://www.swr.noaa.gov/hcd/NMFSSCG.PDF.) 
Nedeau, E., Smith, A.K., and Stone, J., 2009, Freshwater mussels of the Pacific Northwest, (2d ed.):Portland, OR, Xerces Society, Portland, 51 p.

Nelson, M.L., McMahon, T.E., and Thurow, R.F., 2002, Decline of the migratory form in bull charr, Salvelinus confluentus, and implications for conservation: Environmental Biology of Fishes, v. 64, p. 321-332.

Neves, R.J., and Widlak, J.C., 1987, Habitat ecology of juvenile freshwater mussels (Bivalvia: Unionidae) in a headwater stream in Virginia: American Malacological Bulletin, v. 5, p. 1-7.

Neves, R.J., and Widlak, J.C., 1988, Occurrence of glochidia in stream drift and on fishes of the Upper North Fork Holston River, Virginia: American Midland Naturalist, v. 119, p. 111-120.

Neville, H.M., Dunham, J.B., and Peacock, M.M., 2006a, Assessing connectivity in salmonid fishes with DNA microsatellite markers, in Crooks, K., and Sanjayan,M.A., eds., Connectivity conservation: Cambridge, Cambridge University Press, p. 320-342.

Neville, H.M.., Dunham, J.B., and Peacock, M.M., 2006b, Landscape attributes and life history variability shape genetic structure of trout populations in a stream network: Landscape Ecology, v. 21, p. 901-916.

Neville, H., Dunham, J., Rosenberger, A., Umek, J., and Nelson, B., 2009, Influences of wildfire, habitat size, and connectivity on trout in headwater streams revealed by patterns of genetic diversity: Transactions of the American Fisheries Society, v. 138, p.1,314-1,327.

Nichols, J.D., and Williams, B.K., 2006, Monitoring for conservation: Trends in Ecology and Evolution, v. 21, p. 668-673.

Nijhuis, M.J., and Kaplan, R.H., 1998, Movement patterns and life history characteristics in a population of the Cascade torrent salamander (Rhyacotrito cascadae) in the Columbia River Gorge, Oregon: Journal of Herpetology, v. 32, p. 301-304.

Nislow, K.H., Hudy, M., Letcher, B.H., and Smith, E.P, 2011, Variation in local abundance and species richness of stream fishes in relation to dispersal barriers-Implications for management and conservation: Freshwater Biology, v. 56, p. 2,135-2,144.

Nowicki, P., Tirelli, T., Sartor, R.M., Bona, F., and Pessani, D., 2008, Monitoring crayfish using a mark-recapture method—potentials, recommendations, and limitations: Biodiversity and Conservation, v. 17, p. 3,513-3,530.

Olden, J.D., Hoffman, A.L., Monroe, J.B., and Poff, N.L., 2004, Movement behaviors and dynamics of an aquatic insect in a stream benthic landscape: Canadian Journal of Zoology, v. 82 , p. 1,135-1,146.

Olsen, A.R., Sedransk, J., Edwards, D., Gotway, C.A., Liggett, W., and Rathburn, S.L.. and others, 1999, Statistical issues for monitoring ecological and natural resources in the United States: Environmental Monitoring and Assessment, v. 54, p. 1-45.

Pearl, C.A., Adams, M.J., Bury, R.B., Wente, W.H., and McCreary, B., 2009, Evaluating amphibian declines with site revisits and occupancy models-Status of montane anurans in the Pacific Northwest USA: Diversity, v. 1, p. 166-181.

Penna, A.N., 1999, Nature's bounty-Historical and modern environmental perspectives: New York, M.E. Sharpe, Inc., 320 p.

Pess, G., Morley, S., and Roni, P., 2004, Evaluating fish response to culvert replacement and other methods for reconnecting isolated aquatic habitats, in Roni, P., ed., Monitoring stream and watershed restoration:Bethesda, MD, American Fisheries Society, p. 267-276.

Peter, A., 1998, Interruption of the river continuum by barriers and the consequences for migratory fish, in Jungwirth, M., Schmutz, S., and Weiss, S., eds., Fish mgration and fsh bpasses: Oxford, Fishing News Books, p. 99-112. 
Peterson, C.L., 1987, Movement and catchability of the hellbender, Cryptobranchus alleganiensis: Journal of Herpetology, v. 21, p.197-204.

Peterson, J.T., and Dunham, J.B., 2010, Scale and fishery management, in Hubert, W.A., and Quist, M.C., eds., Inland fsheries management (3d ed): Bethesda, MA, American Fisheries Society, p. 81-105.

Pine, W.E., Pollock, K.H., Hightower, J.E., Kwak, T.J., and Rice, J.A., 2003, A review of tagging methods for estimating fish population size and components of mortality: Fisheries, v. 28, p. 10-23.

Pope, K.L., and Matthews, K.R., 2001, Movement ecology and seasonal distribution of mountain yellow-legged frogs, Rana muscosa, in a high-elevation Sierra Nevada basin: Copeia, p. 787793.

Price, D.M., Quinn, T., and Barnard, R.J., 2010, Fish passage effectiveness of recently constructed road crossing culverts in the Puget Sound region of Washington State: North American Journal of Fisheries Management, v. 30, p. 1,110-1,125.

Pringle, C.M., Freeman, M.C., and Freeman, B.J., 2000, Regional effects of hydrologic alterations on riverine macrobiota in the new world-Topical-temperate comparisons: BioScience, v. 50, p. 807-823.

Raeymaekers, J.A.M., Raeymaekers, D., Koizumi, I., Geldof, S., and Volckaert, F.A.M., 2009, Guidelines for restoring connectivity around water mills-A population genetic approach to the management of riverine fish: Journal of Applied Ecology, v. 46, p.562-71.

Raeymaekers, J.A.M., Maes, G.E., Geldof, S., Hontis, I., Nackaerts, K., and Volckaert, F.A.M., 2008, Modeling genetic connectivity in sticklebacks as a guideline for river restoration: Evolutionary Applications, v. 1, p. 475-88.

Railsback, S.F., and Harvey, B.C., 2002, Analysis of habitat-selection rules using an individualbased model: Ecology, v. 83, p.1,817-1,830.

Railsback, S.F., Stauffer, H.B., and Harvey, B.C., 2003, What can habitat preference models tell us? Tests using a virtual trout population: Ecological Applications, v. 13, p. 1,580-1,594.

Reeves, G.H., Williams, J.E., Burnett, K.M., and Gallo, K., 2006, The aquatic conservation strategy of the Northwest Forest Plan: Conservation Biology, v. 20, p. 319-329.

Rieman, B.E., and Dunham, J.B., 2000, Metapopulations and salmonid fishes-A synthesis of life history patterns and empirical observations: Ecology of Freshwater Fish, v. 9, p. 51-64. Rodriguez, M.A., 2002, Restricted movement in stream fish-The paradigm is incomplete, not lost: Ecology, v. 83, p. 1-13.

Roghair, C.N., and Dolloff, C.A., 2005, Brook trout movement during and after recolonization of a naturally defaunated stream reach: North American Journal of Fisheries Management, v. 25, p. 777-784.

Roghair, C., Dolloff, C.A., Nislow, K.H., Krause, C.W., and Walker, J., 2010, Examination of non-game fish passage at road-stream crossings using mark-recapture, genetic, and PIT tag techniques: Pittsburgh, PA, Poster presented at the American Fisheries Society Annual Meeting.

Roni, P., Beechie, T.J., Bilby, R.E., Leonetti, F.E., Pollock, M.M., and Pess, G.R., 2002, A review of stream restoration techniques and a hierarchical strategy for prioritizing restoration in Pacific Northwest Watersheds: North American Journal of Fisheries Management, v. 22, p. $1-20$.

Rosenberg, D.K., Noon, B.R., and Meslow, E.C., 1997, Biological corridors—Form, function, and efficacy: BioScience, v. 47, p. 677-687. 
Royle, J.A., 2006, Site occupancy models with heterogeneous detection probabilities:

Biometrics, v. 62, p. 97-102.

Royle, J.A., Nichols, J.D., and Kéry, M., 2005, Modeling occurrence and abundance of species when detection is imperfect: Oikos, v. 110, p. 353-359.

Sagar, J.P., 2004, Movement and demography of larval coastal giant salamanders (Dicamptodon tenebrosus) in streams with culverts in the Oregon Coast Range [thesis]: Oregon State University, Corvallis, OR, 35 p.

Sagar, J.P., Olson, D.H., and Schmitz, R.A., 2007, Survival and growth of larval coastal giant salamanders (Dicamptodon tenebrosus) in streams in the Oregon Coast Range: Copeia, p. $123-130$.

Schlosser, I.J., 1995, Critical landscape attributes that influence fish population dynamics in headwater streams: Hydrobiologia, v. 303, p. 71-81.

Schmetterling, D.A., and Young, M.K., 2008, Summer movements of boreal toads (Bufo boreas boreas) in two western Montana basins: Journal of Herpetology, v. 42, p. 111-123.

Sheer, M.B., and Steel, E.A., 2006, Lost watersheds-Barriers, aquatic habitat connectivity, and salmon persistence in the Willamette and Lower Columbia River basins: Transactions of the American Fisheries Society, v. 135, p. 1,654-1,669.

Sheldon, A.L., 1968, Species diversity and longitudinal succession in stream fishes: Ecology, v. 49, p. 194-198.

Shoemaker Jr., R.H., 1956, Hydraulics of box culverts with fish-ladder baffles: Highway Research Board Proceedings, v. 35, p.196-209.

Southwood, T.R.E., 1977, Habitat, the templet for ecological strategies?: Journal of Animal Ecology, p. 46, p. 337-365.

Steen, H.K., 2004, The US Forest Service-A history, Centennial Edition: Durham, NC, and Seattle, WA, Forest Service Society in association with University of Washington Press, $356 \mathrm{p}$.

Stoddard, J.L., Larsen, D.P., Hawkins, C.P., Johnson, R.K., and Norris, R.H., 2006, Setting expectations for the ecological condition of streams-The concept of reference condition: Freshwater Bioassessment, v. 16, p.1,267-1,276.

Storfer, A., Murphy, M.A., Spear, S.F., Holderegger, R., and Waits, L.P., 2010, Landscape genetics-Where are we now?: Molecular Ecology, v. 19, p. 3,496-3,514.

Strayer, D.L, Downing, J.A., Haag, W.R., King, T.L., Layzer, J.B., Newton, T.J., and Nichols, S.J., 2004, Changing perspectives on pearly mussels, North America's most imperiled animals: Bioscience, v. 54, p. 429-439.

Taylor, P.D., Fahrig, L., Henein, K., and Merriam, G., 1993, Connectivity is a vital element of landscape structure: Oikos, v. 68, p. 571-573.

Thompson, W.L., Miller, A.E., Mortenson, D.C., and Woodward, A., 2011, Developing effective sampling designs for monitoring natural resources in Alaskan national parks-An example using simulations and vegetation data: Biological Conservation, v. 144, p. 1,270-1,277.

Tsuboi. J., Shinsuke, E,. and Morita, K., 2010, Habitat fragmentation by damming threatens coexistence of stream-dwelling charr and salmon in the Fuji River, Japan: Hydrobiologia, v. 650, p. 223-23.

Turchin, P., 1998, Quantitative analysis of movement-Measuring and modeling population redistribution in animals and plants: Sunderland, MA, Sinauer Associates, Inc., 396 p. 
Urquhart, N.S., and Kincaid, T.M., 1999, Designs for detecting trend from repeated surveys of ecological resources: Journal of Agricultural, Biological, and Environmental Statistics, v. 4, p. 404-414.

U.S.Forest Service, 1999, Roads analysis_-Informing decisions about managing the National Forest Transportation System: Washington, D.C., Misc. Report FS-643, 222 p.

U.S. Forest Service, 2008, Stream simulation-An ecological approach to providing passage for aquatic organisms at road-stream crossings: Stream Simulation Working Group, National Technology and Development Program, 7700-Transportation Management, 0877 1801SDTDC, San Dimas, CA. (Also available at http://www.fs.fed.us/eng/pubs/pdf/ StreamSimulation/index.shtml.)

U.S. Forest Service and Bureau of Land Management, 1994, Standards and guidelines for management of habitat for late-successional and old-growth forest related species within the range of the Northern Spotted Owl, Attachment A to the Record of Decision for amendments to Forest Service and Bureau of Land Management planning documents within the range of the Northern Spotted Owl: Portland, OR, and Moscow, ID, U.S. Forest Service, and Bureau of Land Management, , (Also available online at http://www.blm.gov/or/plans/nwfpnepa/FSEIS1994/newsandga.pdf.)

van Horne, B., 1983, Density as a misleading indicator of habitat quality: The Journal of Wildlife Management, v. 47, p. 893-901.

Vannote, R.L., Minshall, G.W., Cummins, K.W., Sedell, J.R., and Cushing, C.E., 1980, The river continuum concept: Canadian Journal of Fisheries and Aquatic Sciences, v. 37, p. 130-137.

Wahbe, T.R., Bunnell, F.L,. and Bury, R.B., 2000, Defining wildlife habitat areas for tailed frogs, in Darling, L.M., ed., Proccedings of a conference on the biology and management of species and habitats at risk, volume 2: Kamloops, B.C., B.C. Ministry of Environment, Lands and Parks, Victoria, B.C. and University College of the Cariboo, p. 489-495.

Wahbe, T.R., Bunnell, F.L., and Bury, R.B., 2004, Terrestrial movements of juvenile and adult tailed frogs in relation to timber harvest in coastal British Columbia: Canadian Journal of Forest Research, v. 34, p. 2,455-2,466.

Ward, A.J.W., Webster, M.M., and Hart, P.J.B., 2006, Intraspecific food competition in fishes: Fish and Fisheries, v. 7, p. 231-261.

Ward, R.L., Anderson, J.T., and Petty, J.T., 2008, Effects of road crossings on stream and streamside salamanders: Journal of Wildlife Management, v. 72, p. 760-771.

Warren Jr., M.L., and Pardew, M.G., 1998, Road crossings as barriers to small-stream fish movement: Transactions of the American Fisheries Society, v. 127, p. 637-644.

Wigington Jr., P.J., Ebersole, J.L., Colvin, M.E., Leibowitz, S.G., Miller, B., Hansen, B., Lavigne, H., White, D., Baker, J.P., Church, M.R., Brooks, J.R., Cairns, M.A., and Compton J.E., 2006, Coho salmon dependence on intermittent streams: Frontiers in Ecology and Environment, v. 4, p. 513-518.

Williams, B.K., Nichols, J.D., and Conroy, M.J., 2002, Analysis and management of animal populations: San Deigo, CA, Academic Press, 817 p.

Williams, D.D., and Williams, N.E., 1993, The upstream/downstream movement paradox of lotic invertebrates-Quantitative evidence from a Welsh mountain stream: Freshwater Biology, v. 30, p. 199-218.

Williams, J.D., Warren Jr., M.L., Cummings, K.S., Harris, J.L., and Neves, R.J., 1993, Conservation status of freshwater mussels of the United States and Canada: Fisheries, v. 18, p. 6-22. 
Wilzbach, M.A., and Cummins, K.W., 1989, An assessment of short-term depletion of stream macroinvertebrate benthos by drift: Hydrobiologia, v. 185, p. 29-39.

Wilzbach, M.A., Cummins, K.W., and Knapp, R.A., 1988, Toward a functional classification of stream invertebrate drift: Verhandlungen des Internationalen Verein Limnologie, v. 23, p. $1,244-1,254$.

Wirka, J., 2006, Signal crayfish in Stuart Creek: The Ardeid, p. 4-5.

Wofford, J.E.B., Gresswell, R.E., and Banks, M.A., 2005, Influence of barriers to movement on within-watershed genetic variation of coastal cutthroat trout: Ecological Applications, v. 15, p. 628-637.

Wolock, D.M., Winter, T.C., and McMahon, G., 2004, Delineation and evaluation of hydrologiclandscape regions in the United States using geographic information system tools and multivariate statistical analyses: Environmental Management, v. 34, p. S71-S88.

Yamamoto, S., Morita, K., Koizumi, I., and Maekawa, K., 2004, Genetic differentiation of white-spotted charr (Salvelinus leucomaenis) populations after habitat fragmentation: Spatialtemporal changes in gene frequencies: Conservation Genetics, v. 5, p. 529-538. 


\section{Appendix}

\section{General Movement Characteristics and Impact Summaries}

Fish - The many different types and patterns of movement of fish vary by species and life stage. These movements and patterns range from limited and localized movement within a small home range or territory, roundtrip exploratory ranging movements into areas outside of their home range, one-way dispersal to a new location, regular and predictable long-distance roundtrip migrations, as well as accidental displacement due to stochastic environmental events that impact stream dynamics. Many species can be quite mobile and their patterns of movement can extend over long temporal and large spatial scales, are fundamental to the persistence of populations across generations, and are an expression of their diverse life histories and capacity to respond to dynamic environmental conditions and events. Fish species are differentially susceptible to barriers to upstream movement, with vulnerability increasing relative to increasing spatial mobility. Potential impacts include: (1) reduction or elimination of the ability of fish to disperse to or reach upstream habitats; (2) eventual extirpation of mobile life history types from upstream populations; (3) fragmentation and isolation of upstream populations; (4) increased vulnerability to the negative effects of stochastic environmental and habitat disturbances; (5) restriction of upstream populations to potentially marginal and degraded habitats and prevention of the recolonization of disturbed upstream habitats; and (6) population-level genetic impacts, such as the disruption of gene flow from downstream populations, increased genetic drift in upstream populations, development of genetic bottlenecks and loss of genetic diversity, and reduced effective population. Primary references used for this summary include: Grant and Noakes (1987), Gowan and others (1994), Fausch and Young (1995), Schlosser (1995), Griswold (1996), Peter (1998), Hilderbrand and Kershner (2000), Pringle and others (2000), Castric and others(2001), Kruse and others (2001), Nelson and others (2002), Rodriguez (2002), Dunham and others (2003), Jackson (2003), Yamamoto and others (2004), Colyer and others (2005), Wofford and others (2005), Ebersole and others (2006), Fausch and others (2006 and references contained therein), Neville and others (2006a, 2006b), Wigington and others (2006), and Guy and others (2008).

Amphibians - Species inhabiting watersheds of relatively simple structure typically are restricted to a single stream; whereas in watersheds with a high level of drainage complexity and connectivity, adults (and to a lesser extent transformed juveniles) are capable of inter-stream and inter-catchment dispersal. Mode and pattern of amphibian movement and level of activity, within streams and along stream corridors, varies directly with life stage. The larval movement pattern of species that breed in streams tends to be relatively limited (for example, average of $<30$ $\mathrm{m} /$ summer) and localized (within and among channel units). Larvae (as well as juveniles and adults), however, are susceptible to accidental displacement downstream during high-flow events. Individuals that transform to the terrestrial life stage (juveniles and adults) can occupy home ranges of varying sizes within a stream riparian area (for example, 12-350 m along a streambank). Adults that breed in wetlands, ponds, and lakes (primarily frogs and toads) can migrate overland to breeding sites. These migrations tend to be relatively rapid and of varying distance. Riparian areas and stream channels are used by juveniles and adults as migration 
corridors, with some species capable of moving as much as $670 \mathrm{~m} / \mathrm{d}$ and up to $1.5 \mathrm{~km}$ over a period of 6 days. Frogs and toads, in general, move upstream and overland (transformed juveniles and adults) in spring and summer, and downstream movements have been associated with heavy rain events. Frogs and toads also have been shown to be somewhat susceptible to barriers to upstream movement, with artificial structures affecting direction of movement; however, this group is known to be capable of moving through slotted-drain culverts designed to facilitate amphibian passage. Salamanders, in general, move upstream in spring and summer and downstream in winter; transformed juveniles and adults can move overland, typically within stream riparian areas; have been shown to be somewhat susceptible to barriers to upstream movement (although results are mixed); and are responsive to road-stream crossing structures that are as wide as the stream channel, at the same grade as the streambed, and contain rubble substrate. Primary references used for this summary include: Martof (1953), Carpenter (1954), Ashton (1975), Daugherty and Sheldon (1982), Peterson (1987), Kay (1989), Gibbs (1998), Nijhuis and Kaplan (1998), Wahbe and others (2000, 2004), Pope and Mathews (2001), Lowe and Bolger (2002), Knapp and others (2003), Lowe (2003), Sagar (2004), Adams and others (2005), Matsuda and Richardson (2005),Hayes and others (2006), Burkholder and Diller (2007), Sagar and others (2007), Schmetterling and Young (2008), Ward and others (2008), Cosentino and others (2009), and Campbell Grant and others (2010).

Aquatic Insects - Mode and pattern of movement and level of activity varies with species and life stage. In general, activity and range of movement is limited and localized, with downstream drift recognized as being the primary mechanism for longer downstream movement. Drift is active when individuals select to enter the stream current for transport to new locations with increased availability of resources for growth and survival. Drift also can be passive or accidental when caused by stochastic environmental events. Research indicates that drift is a response correlated with upstream density-related factors and initially causes a decrease in density. Population densities upstream, however, are most probably maintained because recruitment from upstream oviposition by non-drifting individuals is sufficient to over-ride depletion due to downstream drift, rather than upstream flight of adults which can be both random and directional. Aquatic insects have differing abilities and opportunities for dispersal, related in part to the complexity and connectivity of streams and drainage networks. Species in isolated streams are predominantly restricted to a single stream, while flying adults are capable of inter-stream and inter-catchment dispersal in drainages with high complexity and connectivity. Aquatic insects, in general, do not appear to be overly susceptible to barriers to upstream passage. Primary references used for this summary include: Bird and Hynes (1981), Wilzbach and others (1988),Wilzbach and Cummins (1989), Williams and Williams (1993), Lancaster (1999, 2008), Bilton and others (2001), Malmqvist (2002), and Olden and others (2004).

Crayfish - The general pattern of movement of crayfish is characterized by a relatively long period of limited, localized activity in a relatively small home range, followed by an episode of longer distance dispersal to a new location or home range. The direction of dispersal can be downstream or upstream. Some species appear to be susceptible to accidental displacement downstream during high-flow events. These events are usually followed by a period of dispersal upstream as flow decreases. This group has been documented to be susceptible to barriers to upstream passage. Primary references used for this summary include: Merkle (1969), Gherardi and others (2000), Bubb and others (2002)), Bubb and others (2004, 2005, 2006), Kerby and others (2005), and Wirka (2006). 
Mussels - Species of the order Unionoida are highly sedentary and their movement and level of activity is life-stage specific. Glochidia (larvae) are the most highly "mobile” life-stage; their pseudo-mobility is determined by the movement characteristics of the host fish species to which they attach. Juveniles, after releasing from attachment to their hosts, burrow into sediment where they are relatively immobile. Adults remain primarily immobile in soft bottom substrates, although they can and do undertake limited short-range movements. The susceptibility of this group to upstream passage barriers is most likely directly related to the susceptibility to passage barriers of the fish species that are hosts to glochidia. Primary references used for this summary include: Neves and Widlak (1987, 1988), Williams and others (1993), Hovingh (2004), Nedeau and others (2009), and Mock and others (2010). 


\section{Fish: General movement patterns of stream fish as expressed by 21 species (1 of 5)}

\begin{tabular}{|c|c|c|c|}
\hline SPECIES & DOMINANT TYPES OF MOVEMENT & GENERAL MOVEMENT PATTERNS & STUDY LOCATIONS \\
\hline $\begin{array}{l}\text { - Bonneville Cutthroat Trout } \\
\text { (Oncorhynchus clarkii utah) }\end{array}$ & $\begin{array}{l}\text { - Station keeping: summer-winter } \\
\text { - Migratory: spawning; spring }\end{array}$ & $\begin{array}{l}\text { - Relatively mobile, although seasonal } \\
\text { - Greatest movement activity and } \\
\text { distance: spring (spawning, post- } \\
\text { spawning) } \\
\text { - Variable-sporadic movement and } \\
\text { limited distance: summer-winter }(\leq 0.5 \\
\mathrm{km})\end{array}$ & $\begin{array}{ll}\text { - } & \text { southeastern Idaho } \\
\text { - } & \text { western Wyoming } \\
\text { - } & \text { northern Utah }\end{array}$ \\
\hline $\begin{array}{l}\text { - Coastal Cutthroat Trout (Oncorhynchus } \\
\text { clarkii clarkii) }\end{array}$ & $\begin{array}{l}\text { - Station keeping } \\
\text { o No movement (0 channel units) } \\
\text { o Local movement (1-5 channel units) } \\
\text { o Longer distance movements ( }>5 \\
\text { channel units) } \\
\text { o Pulsed movement (variable } 1-3 \\
\text { above) }\end{array}$ & $\begin{array}{l}\text { - Relatively short within-basin distances, } \\
\text { primarily at the channel unit-scale with } \\
\text { smaller proportion of population } \\
\text { making reach- and segment-scale } \\
\text { movements } \\
\text { - Seasonal component } \\
\text { o Greatest movement in April } \\
\text { o Least movement in October } \\
\text { - Unit-scale movements common } \\
\text { throughout year } \\
\text { - Reach- and segment-scale movements } \\
\text { typically occur in winter and spring } \\
\end{array}$ & $\begin{array}{l}\text { - western British Columbia } \\
\text { - southwestern Oregon }\end{array}$ \\
\hline $\begin{array}{l}\text { - Westslope Cutthroat Trout } \\
\text { (Oncorhynchus clarkii lewisi) }\end{array}$ & $\begin{array}{l}\text { - Station keeping: summer and winter } \\
\text { - Migratory: fall downstream; spring } \\
\text { upstream }\end{array}$ & $\begin{array}{l}\text { - Seasonal, long distances, wide-spread } \\
\text { distribution } \\
\text { o Fall: downstream migration up to } \\
194 \text { km } \\
\text { o Winter: sedentary downstream } \\
\text { o Spring: upstream migration up to } 475 \\
\text { km } \\
\text { o Summer: sedentary upstream } \\
\text { - Many individuals demonstrate homing } \\
\text { behavior, returning to the same } \\
\text { upstream channel habitat previously } \\
\text { occupied }\end{array}$ & $\begin{array}{l}\text { - } \text { central Idaho } \\
\text { - central Oregon }\end{array}$ \\
\hline
\end{tabular}




\section{Fish: General movement patterns of stream fish as expressed by 21 species ( 2 of 5 )}

\begin{tabular}{|c|c|c|c|}
\hline SPECIES & DOMINANT TYPES OF MOVEMENT & GENERAL MOVEMENT PATTERNS & STUDY LOCATIONS \\
\hline - Bull Trout (Salvelinus confluentus) & $\begin{array}{l}\text { - Station keeping } \\
\text { - Migratory: variable distances for } \\
\text { spawning and return to non-spawning } \\
\text { habitat }\end{array}$ & $\begin{array}{l}\text { - Seasonal upstream and downstream } \\
\text { migrations vary by: } \\
\text { o Population } \\
\text { o Time of year (spring, fall) } \\
\text { o Distance (reported mean distances of } \\
33 \text { and } 63 \mathrm{~km} \text {; range 9-129 km) } \\
\text { - Migrations usually occur at night and } \\
\text { are relatively rapid } \\
\text { - Individuals typically return to or near } \\
\text { sites from which they migrated } \\
\text { - Juvenile emigration from natal habitat } \\
\text { can occur in two pulses (spring and fall) } \\
\text { - juveniles can stay in natal tributaries } \\
\text { for up to } 3 \text { years } \\
\text { - Some populations can be non-migratory } \\
\text { residents in headwater tributaries }\end{array}$ & $\begin{array}{l}\text { - } \text { northwestern Washington } \\
\text { - northwestern Idaho } \\
\text { - northwestern Montana }\end{array}$ \\
\hline - Brook Trout (Salvelinus fontinalis) & - Station keeping with upstream dispersal & $\begin{array}{l}\text { - Upstream dispersal typically occurs in } \\
\text { summer } \\
\text { - Movement of up to } 3.4 \mathrm{~km} \text { relatively } \\
\text { common }\end{array}$ & $\begin{array}{ll}\text { - } & \text { central Idaho } \\
\text { - } & \text { northern Colorado }\end{array}$ \\
\hline $\begin{array}{l}\text { - Mountain Whitefish (Prosopium } \\
\text { williamsoni) }\end{array}$ & $\begin{array}{l}\text { - } \text { Station keeping } \\
\text { - } \text { Migratory: roundtrip to over-wintering } \\
\text { habitat }\end{array}$ & $\begin{array}{l}\text { - Variable types of seasonal movement } \\
\text { o Single summer reach-no fall } \\
\text { migration } \\
\text { o Single summer reach-fall migration } \\
\text { to over-wintering habitat-return to } \\
\text { summer habitat (3-95 km) } \\
\text { o Multiple summer reaches-fall } \\
\text { migration to over-wintering habitat- } \\
\text { return to summer habitat } \\
\text { o Summer reach-fall migration to over- } \\
\text { wintering habitat-no return to } \\
\text { summer habitat }\end{array}$ & $\begin{array}{l}\text { - } \text { northeastern Oregon } \\
\text { - } \text { southeastern Washington }\end{array}$ \\
\hline
\end{tabular}




\section{Fish: General movement patterns of stream fish as expressed by 21 species ( 3 of 5 )}

\begin{tabular}{|c|c|c|c|}
\hline SPECIES & DOMINANT TYPES OF MOVEMENT & GENERAL MOVEMENT PATTERNS & STUDY LOCATIONS \\
\hline $\begin{array}{l}\text { - Largescale Sucker (Catostomus } \\
\text { macrocheilus) }\end{array}$ & $\begin{array}{l}\text { - Station keeping } \\
\text { - Migratory: roundtrip to over-wintering } \\
\text { habitat }\end{array}$ & $\begin{array}{l}\text { - Seasonal movement from upstream } \\
\text { habitats (spring-early summer) to } \\
\text { downstream over-wintering habitats } \\
\text { (beginning mid-summer through early } \\
\text { fall) } \\
\text { - Can be long distance movements: } 17 \text { - } \\
300 \mathrm{~km} \text {; mean = } 111 \mathrm{~km} \\
\text { - } \text { Minimal movement during winter } \\
\text { - } \text { Return to upstream habitats in spring }\end{array}$ & $\begin{array}{l}\text { - } \text { northeastern Oregon } \\
\text { - } \text { southeastern Washington }\end{array}$ \\
\hline - Coastrange Sculpin (Cottus aleuticus) & $\begin{array}{l}\text { - Station keeping } \\
\text { - Ranging: short-distances downstream }\end{array}$ & $\begin{array}{l}\text { - Distributed throughout mainstem and } \\
\text { tributaries } \\
\text { - In longer systems: downstream } \\
\text { migration (transport) of larvae toward } \\
\text { estuaries with subsequent upstream } \\
\text { migration of young and some older } \\
\text { individuals } \\
\text { - In shorter systems: downstream } \\
\text { spawning migration of adults with } \\
\text { subsequent upstream migration of } \\
\text { young and older individuals } \\
\end{array}$ & - coastal northern California \\
\hline - Prickly Sculpin (Cottus asper) & $\begin{array}{l}\text { - Station keeping } \\
\text { - Ranging -Migration: inter-tributary }\end{array}$ & $\begin{array}{l}\text { - Distributed throughout mainstem and } \\
\text { tributaries } \\
\text { - Movement between mainstem and } \\
\text { tributaries (and vice versa) } \\
\text { - No apparent downstream transport of } \\
\text { larvae or migration of adults with } \\
\text { subsequent upstream migration of } \\
\text { young and older individuals }\end{array}$ & - coastal northern California \\
\hline - Torrent Sculpin (Cottus rhotheus) & $\begin{array}{l}\text { - } \text { Station keeping } \\
\text { - Limited Migration }\end{array}$ & $\begin{array}{l}\text { - } \text { Restricted to clear, cold streams with } \\
\text { swift current } \\
\text { - Limited migration to upstream } \\
\text { spawning sites by adults } \\
\text { - Larvae emerge around early August, } \\
\text { and drift and disperse downstream } \\
\text { (suggests upstream migration of young } \\
\text { individuals) }\end{array}$ & $\begin{array}{l}\text { - } \text { northwestern Montana } \\
\text { - Columbia River basin of the Pacific } \\
\text { Northwest }\end{array}$ \\
\hline
\end{tabular}


Fish: General movement patterns of stream fish as expressed by 21 species (4 of 5)

\begin{tabular}{|c|c|c|c|}
\hline SPECIES & DOMINANT TYPES OF MOVEMENT & GENERAL MOVEMENT PATTERNS & STUDY LOCATIONS \\
\hline - Mottled Sculpin (Cottus bairdi) & - Station keeping & $\begin{array}{l}\text { - Restricted movement }(1.3-4.4 \mathrm{~m} \text { over } \\
45 \text { days }) \text { with sedentary and "mobile" } \\
\text { individuals } \\
\text { - Small home range = } 12.9 \text { m linear } \\
\text { stream distance } \\
\text { - Maximum distance traveled = } 55 \mathrm{~m} \\
\text { - Juvenile movement influenced by } \\
\text { interactions with adults and stream flow } \\
\text { - Adult movement influenced by } \\
\text { competitive interactions for suitable } \\
\text { space (habitat) }\end{array}$ & - western North Carolina \\
\hline $\begin{array}{l}\text { - Longnose Dace (Rhinichthys } \\
\text { cataractae) }\end{array}$ & - Station keeping & $\begin{array}{l}\text { - } \text { Restricted movement } \\
\text { - Small home range = } 13.7 \mathrm{~m} \text { linear } \\
\text { stream distance } \\
\text { - } \text { Maximum distance traveled = } 40 \mathrm{~m} \\
\text { - } \text { Territorial during spawning and } \\
\text { incubation } \\
\text { - } \text { Limited movement or transport out of } \\
\text { home range }\end{array}$ & - western North Carolina \\
\hline - Blacknose Dace (Rhinichthys atratulus) & - Station keeping & $\begin{array}{l}\text { - Restricted movement } \\
\text { - Seasonal habitat shift: } \\
\text { o Late November = crevices under } \\
\text { rubble } \\
\text { o Late March = open water } \\
\text { - Can be territorial during spawning } \\
\text { - Short relocation movements in response } \\
\text { to predators }\end{array}$ & - southern Ontario \\
\hline $\begin{array}{l}\text { - Rosyside Dace (Clinostomus } \\
\text { funduloides) }\end{array}$ & - Station keeping & $\begin{array}{ll}\text { - } & \text { Restricted movement } \\
\text { - } & \text { Small home range = } 19.3 \mathrm{~m} \text { linear } \\
\text { stream distance } \\
\text { - } \text { Maximum distance traveled = } 98 \mathrm{~m}\end{array}$ & - western North Carolina \\
\hline
\end{tabular}


Fish: General movement patterns of stream fish as expressed by 21 species ( 5 of 5 )

\begin{tabular}{|c|c|c|c|}
\hline SPECIES & DOMINANT TYPES OF MOVEMENT & GENERAL MOVEMENT PATTERNS & STUDY LOCATIONS \\
\hline $\begin{array}{l}\text { - Central Stoneroller (Campostoma } \\
\text { anomalum) }\end{array}$ & - Station keeping & $\begin{array}{l}\text { - } \text { Restricted movement } \\
\text { - Small home range = } 35.2 \mathrm{~m} \text { linear } \\
\text { stream distance } \\
\text { - } \text { Maximum distance traveled = } 135 \mathrm{~m} \\
\text { - } \text { Most marked individuals recaptured in } \\
\text { initial capture pool or riffle }\end{array}$ & - Ohio \\
\hline $\begin{array}{l}\text { - Smallmouth Bass (Micropterus } \\
\text { dolomieui) }\end{array}$ & $\begin{array}{l}\text { - Station keeping - ranging } \\
\text { - Migration }\end{array}$ & $\begin{array}{l}\text { - Varies seasonally } \\
\text { o Fall: sedentary or migrate }>45 \mathrm{~m} \text { to } \\
\text { winter habitat } \\
\text { o Winter: typically inactive in deep } \\
\text { water; however some individuals are } \\
\text { active with regular short-term } \\
\text { movement } \\
\text { o Spring: spawn in mainstem or move } \\
\text { from mainstem to spawn in } \\
\text { tributaries; can move long distances } \\
\text { in mainstem ( } 38 \text { mi) and tributaries } \\
\text { ( } 3 \text { mi) } \\
\text { o Summer: migrate to summer habitat } \\
\text { with restricted area (e.g., single pool) } \\
\text { and movement; although home range } \\
\text { size varies (i.e., } 70 \text { yards to } 1 \text { mile) } \\
\text { and movement distance can be up to } \\
3 \text { miles }\end{array}$ & $\begin{array}{l}\text { - southwestern Wisconsin } \\
\text { - Alabama } \\
\text { - Tennessee } \\
\text { - Massachusetts } \\
\text { - Oregon } \\
\text { - Ontario } \\
\text { - Michigan }\end{array}$ \\
\hline 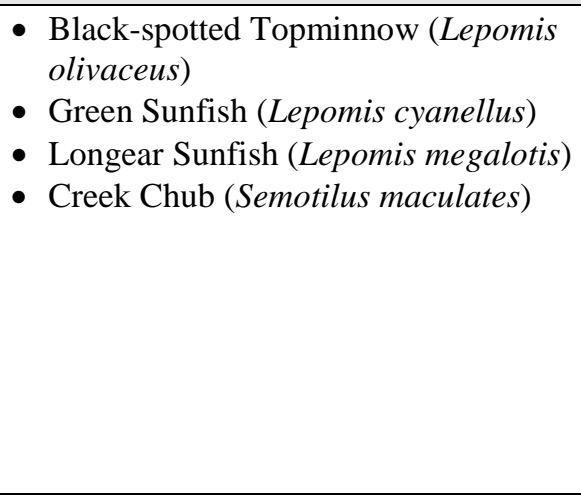 & $\begin{array}{l}\text { - Station keeping } \\
\text { - Limited Ranging }\end{array}$ & $\begin{array}{l}\text { - Movement generally not complex } \\
\text { - Restricted (“non-mobile") movement: } \\
67-88 \text { percent of recaptured individuals } \\
\text { did not move out of pool of initial } \\
\text { capture } \\
\text { - "Mobile" individuals: fish captured } \\
\text { outside of pool of initial capture (12-33 } \\
\text { percent) } \\
\text { o Typically captured in adjacent pools } \\
\text { o } 70 \text { percent moved }<100 \mathrm{~m} \\
\text { o Longest distances moved = } 453 \text { and } \\
506 \mathrm{~m}\end{array}$ & - Arkansas (Ouachita River drainage) \\
\hline
\end{tabular}


Frogs and Toads: General movement patterns

\begin{tabular}{|c|c|c|}
\hline LIFE STAGE & GENERAL MOVEMENT PATTERNS & SPECIES \\
\hline - Larval & $\begin{array}{l}\text { - In-stream movement } \\
\text { - Reported maximum distance moved during } 3 \text { summer } \\
\text { field seasons = 64 m in old-growth streams and } 3 \mathrm{~m} \text { in } \\
\text { clearcut streams } \\
\text { - Movement tends to be downstream from egg } \\
\text { deposition sites located near source of streams }\end{array}$ & - Ascaphus truei \\
\hline - Juvenile and Adult & $\begin{array}{l}\text { - Movement typically semi-aquatic and terrestrial in } \\
\text { stream riparian areas } \\
\text { - Adults of species that breed at wetland and lentic } \\
\text { locations can undertake overland migratory } \\
\text { movements to these sites } \\
\text { - Juveniles that transform at wetland and lentic sites } \\
\text { migrate overland back to stream sites } \\
\text { - Streams and stream riparian areas are also used as } \\
\text { migration corridors by juveniles and adults } \\
\text { - Home ranges have been estimated to be } 12-350 \mathrm{~m} \\
\text { along stream banks } \\
\text { - Species such as } B \text {. b. boreas have been documented to } \\
\text { move } 1.5 \mathrm{~km} \text { upstream over a period of } 6 \text { days } \\
\text { - Some species can move } 10-670 \mathrm{~m} / \text { day }\end{array}$ & $\begin{array}{l}\text { - Ascaphus truei } \\
\text { - Bufo boreas boreas } \\
\text { - Hyla cadaverina } \\
\text { - Rana clamitans } \\
\text { - Rana muscosa } \\
\text { - Rana palustris } \\
\text { - Rana pipiens } \\
\text { - Rana pretiosa pretiosa } \\
\text { - Rana sylvatica }\end{array}$ \\
\hline
\end{tabular}




\section{Salamanders: General movement patterns}

\begin{tabular}{|c|c|c|}
\hline LIFE STAGE & GENERAL MOVEMENT PATTERNS & SPECIES \\
\hline - Larval and Gilled-Adult (neotene) & $\begin{array}{l}\text { - In-stream movement } \\
\text { - Movement tends to be relatively localized with ability } \\
\text { to move documented to be up to } 19 \mathrm{~m} / \text { day, an average } \\
\text { of }<30 \mathrm{~m} \text { during } 2 \text { summer field seasons, and } 51 \mathrm{~m} / 2 \\
\text { month period } \\
\text { - Spring-summer in-stream movement is primarily } \\
\text { upstream } \\
\text { - Tend to move downstream in winter } \\
\text { - Presence of pipe culverts and culverts with perched } \\
\text { outlets have been shown to impair larval upstream } \\
\text { passage }\end{array}$ & $\begin{array}{l}\text { - Dicamptodon tenebrosus } \\
\text { - Gyrinophilus porphyriticus } \\
\text { - Pseudotriton ruber } \\
\text { - Rhyacotriton variegatus }\end{array}$ \\
\hline - Juvenile and Adult (transformed) & $\begin{array}{l}\text { - Movement typically semi-aquatic and terrestrial in } \\
\text { stream riparian areas and relatively localized (e.g., up } \\
\text { to } 4 \mathrm{~m} \text { /day) } \\
\text { - Home range can be up to } 85 \mathrm{~m} \text { along stream bank } \\
\text { - Juveniles have been documented to move as much as } \\
600 \mathrm{~m} \text { along stream bank } \\
\text { - Summer movement primarily upstream } \\
\text { - Winter movement primarily downstream } \\
\text { - Presence of culverts have been shown to affect } \\
\text { upstream passage }\end{array}$ & $\begin{array}{l}\text { - Cryptobranchus alleganiensis } \\
\text { - Desmognathus fuscus } \\
\text { - Dicamptodon ensatus } \\
\text { - Dicamptodon tenebrosus } \\
\text { - Gyrinophilus porphyriticus } \\
\text { - Rhyacotriton kezeri } \\
\text { - Rhyacotriton olympicus } \\
\text { - Rhyacotriton variegatus }\end{array}$ \\
\hline
\end{tabular}




\section{Aquatic Insects: General movement patterns}

\begin{tabular}{|c|c|c|c|}
\hline TYPE OF MOVEMENT & LIFE-STAGE & PATH & ACTIVE- PASSIVE \\
\hline - Crawling and Swimming & Larval - Adult & Localized - Multidirectional & Active \\
\hline - Flying & Adult & Multidirectional & Active \\
\hline - Drift & Larval - Adult & Downstream & Active - Passive \\
\hline - Rafting - Egg Broadcast & Egg - Larval & Localized and Downstream & Passive \\
\hline
\end{tabular}

\section{CAVEATS:}

- Typical periods of no movement: pupation, diapause, eggs - early instars.

- Upstream flight of adults probably more random than directional.

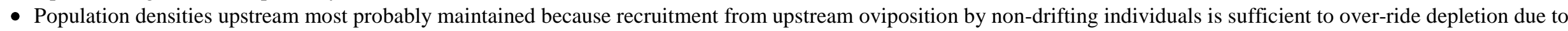
downstream drift.

- Habitat heterogeneity in streams is high and the range of local environmental conditions can be wide.

- In general, taxonomic richness is highly variable, and species richness increases with stream size and is highest in mid-order streams.

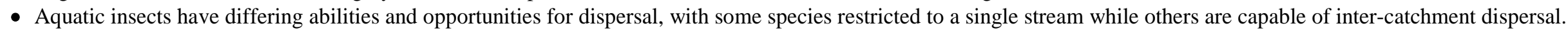

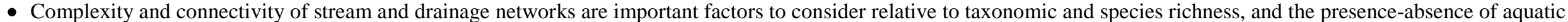
invertebrates. 


\section{Crayfish and Mussels: General movement patterns}

\begin{tabular}{|c|c|c|}
\hline GROUP - SPECIES & DOMINANT TYPES OF MOVEMENT & GENERAL MOVEMENT PATTERNS \\
\hline - Red Swamp Crayfish (Procambarus clarkii) & $\begin{array}{l}\text { - Station keeping } \\
\text { - Ranging (episodic dispersal) }\end{array}$ & $\begin{array}{l}\text { - Typically stationary with periods of episodic } \\
\text { movement to new location up- or downstream }\end{array}$ \\
\hline - Signal Crayfish (Pacifasticus lenisculus) & - Stationary to relatively mobile & $\begin{array}{l}\text { - Active downstream movement: median maximal } \\
\text { distance = } 15 \mathrm{~m} \text { (range }=0-417 \mathrm{~m} \text { ) } \\
\text { - Active upstream movement: median maximal distance } \\
=13.5 \mathrm{~m} \text { (range }=0-283 \mathrm{~m} \text { ) } \\
\text { - Capable of range expansion up to } 2.4 \mathrm{~km} / \mathrm{y} \\
\text { - Passive downstream movement due to drift or flushing } \\
\text { during high-flow events followed by upstream } \\
\text { dispersal with decreasing flow } \\
\text { - Susceptible to barriers to upstream movement }\end{array}$ \\
\hline - Mussels (Unionoida) & - Stationary with pseudo-mobility & $\begin{array}{l}\text { - Movement is life stage dependent } \\
\text { o Glochidia (larvae): parasitize host (typically fish) } \\
\text { and their mobility is determined by movement } \\
\text { characteristics of host } \\
\text { o Juveniles: release from host and burrow into } \\
\text { sediment until mature } \\
\text { o Adults: highly sedentary with limited mobility }\end{array}$ \\
\hline
\end{tabular}




\section{Study Examples: Passage Impairment and Habitat Loss}

Fish: Cyprinids.—Bouska and Paukert (2010) conducted a mark-recapture study of fish passage at 5 concrete box culverts, 5 low-water crossings (concrete slabs vented by culverts), and 10 control sites in northeastern Kansas streams. Fish $(n=6,159)$ were marked between mid-April and the end of May and recaptured June through August. Of the 698 individuals recaptured, 530 of them were cyprinids (common shiner, Luxilus cornutus; red shiner, Cyprinella lutrensis; redfin shiner, Lythrurus umbratilis; and southern red-belly dace, Phoxinus erythrogaster). They found that on average 64 percent of recaptured cyprinids were present upstream of box culverts, but only 23 percent were recaptured upstream of low-water crossings. An additional 199 Topeka Shiners (Notropis Topeka), a species listed as federally endangered, were marked during this study. Of the 32 individuals recaptured at low-water crossings, none were recaptured above a crossing, and only 1 of 5 individuals recaptured at box culverts was recaptured above a culvert. Bouska and Paukert (2010) were able to quantify the extent of fish passage impairment caused by the road-stream crossing structures, and correlated the decrease in upstream passage with increase in culvert slope and length, decrease in culvert width, and increase in culvert perching.

Fish: Westslope Cutthroat and Brook Trout.—Burford and others (2009) assessed the status of populations of westslope cutthroat trout (Oncorhynchus clarkii lewisi) and brook trout (Salvelinus fontinalis) upstream and downstream of 23 suspected barrier culverts in the Upper Clearwater drainage of western Montana, and investigated the direct passage of marked fish through a subset of 12 culverts. They used single-pass electrofishing to sample and estimate population size, and captured marked fish in upstream trap boxes to assess passage impairment. Westslope cutthroat trout were present at 22 of the 23 sites, and upstream and downstream population estimates were equitable at 19 sites. Brook trout were present at 15 of the 23 sites, and abundance estimates upstream and downstream of culverts was equitable at 12 sites. At the 12 passage experiment culverts, and for the species combined: (1) the proportion of marked fish captured upstream of the culverts (0.37) was significantly lower than the proportion of marked fish captured upstream in natural stream reaches (0.63); and (2) passage restriction was significant at 6 of the culverts. In general, Burford and others (2009) attributed passage impairment to the distance of culvert oulet drop and size of individual, with smaller fish (that is, $<100 \mathrm{~mm}$ ) increasingly unable to move through culverts with increasingly higher distances from outlet lip to water surface (starting at $21-24 \mathrm{~cm}$ ). Although this study demonstrated that the ability of marked individuals to move through culverts was differentially affected relative to size, this impairment did not appear to impact the abundances of populations of both species upstream of a number of the study culverts.

Fish: Steelhead and Chinook Salmon.- Sheer and Steel (2006) examined the potential affects of the presence of 1,491 anthropogenic barriers (including culverts) in the Willamette and Lower Columbia River basins (Oregon and Washington) on anadromous steelhead

(Oncorhynchus mykiss) and Chinook salmon (Oncohrynchus tshawytscha). They determined that these fish passage barriers blocked 14,931 km of streams within the basins. The loss of stream habitat varied substantially across watersheds; however, barriers of all kinds have reduced the percent of original stream habitat accessible to anadromous salmonids by 50 percent, and barriers have decreased the connectivity of these habitats. Specifically, in Willamette River drainage basins, one-half of 1st- and 2nd-order tributaries where salmon typically spawn are not 
accessible. Sheer and Steel (2006) also found that the amount of lost habitat and number of small lowland barriers were highly predictive of decreases of spring Chinook populations. Overall, anthropogenic barriers in these river basins have contributed to alteration of basin landscapes, limited the access of anadromous salmonids to critical stream habitats, and negatively affected the status of populations throughout the two basins.

Amphibians: Salamanders._-Sagar (2004) and Sagar and others (2007) studied the potential effects of the presence of culverts in Oregon Coast Range streams on coastal giant salamander (Dicamptodon tenebrosus) larvae. Study sites in nine culvert streams were located with the culvert centered within a sampling reach of about $80 \mathrm{~m}$. Although larvae were highly sedentary, Sagar (2004) found that they moved less frequently through reaches with culverts compared to non-culvert stream reaches; that culvert type affected the frequency of upstream movement through and density of larvae in culverts (Arch Culvert movement and density > Pipe Culvert movement and density); and that larval density also was correlated with the presence of large substrates in culverts and adjacent stream reaches. Larval survival, however, was not well correlated with culvert presence, and no effects on growth were detected (Sagar and others, 2007).

\section{Study Examples: Species and Life History - Differential Impact}

Amphibians: Salamanders. - Ward and others (2008) sampled salamander species inhabiting streams in 3 sub-drainage basins of eastern West Virginia. They sampled 18 reaches at 9 culvert sites and 14 reaches at 7 reference sites, capturing 477 salamanders representing 6 species. Their data suggest that the presence of roads and culverts did not appear to affect the overall abundance of all salamander species combined at a site; however, this was due, in part, to an increase at road-stream crossings in the abundance of the northern two-lined salamander (Eurycea bislineata), which is a habitat generalist capable of inhabiting disturbed habitats and dispersing through the terrestrial environment. The use of multiple pathways for dispersal has been shown to facilitate amphibian persistence in streams (Campbell Grant and others, 2010). Ward and others (2008) also speculated that differences between salamander communities upstream and downstream of culverts (for example, composition and abundance of individual species) could be attributed to the presence of hanging culverts and lack of streambed substrate within culverts.

Invertebrates: Benthic Macroinvertebrates.—Khan and Colbo (2008) studied the abundance and composition of species comprising benthic macroinvertebrate communities in three streams with culverts on the Avalon Peninsula of Newfoundland, Canada. They sampled five sites upstream and downstream of a culvert located in each stream, and found that the abundance of certain taxa was decreased by disturbance due to the presence of the culvert, but that community composition was not affected. The decrease in abundance was highest in plunge pools downstream of the culverts due to what they defined as hydraulic disturbance. This impact was determined to be spatially limited and similar to the type of disturbance found downstream of small waterfalls and chutes in streams without culverts. 


\section{Study Examples: Potential Positive Effects of Restricted Upstream Passage}

Non-Native and Invasive Species: Salmonids and Crayfish.-In some cases, culverts and other barriers to upstream passage may actually benefit native species, especially threatened and endangered populations that are susceptible to the negative effects of encroachment by nonnative and potentially invasive species. Fausch and others $(2006,2009)$ summarize the numerous negative effects that salmonid populations could experience when isolated upstream of barriers to upstream movement. They also describe conditions when the potential effects of upstream isolation might be less deleterious than being invaded by downstream non-native salmonid species. Invasive species, such as crayfish also have been identified as a major threat to stream ecosystems, affecting the distributions, abundances, and persistence of native species and populations. In central and southern California, native populations of the California newt (Taricha torosa) have been extirpated from stream reaches where non-native red swamp crayfish (Procambarus clarkia) are present (Kerby and others, 2005); and several species of native amphibians have decreased in a stream invaded by the signal crayfish (Pacifastucus lenisculus; Wirka, 2006). In each of these cases, populations of the native species upstream of barriers that prohibit the upstream movement of crayfish remain unaffected and relatively robust. In their reviews of this phenomenon, Fausch and others $(2006,2009)$ have articulated a conceptual framework (2009) and strategies (2006) that can be used by land managers to assess the positive and negative attributes of maintaining stream structures as barriers to the upstream movement of non-native species for minimizing their impact on native populations. They propose that any decision made to maintain barriers needs to be made in the context of the conservation value of the native species or population; the vulnerability to invasion and displacement by non-native species of the native population; the potential of extinction of the native population if isolated; and how the retention of upstream movement barriers among multiple populations potentially threatened by non-native species will be prioritized. 


\section{Invited Attendees at the Aquatic Organism Passage Workshop: Guidelines for an Effectiveness Monitoring Protocol, Held March 16-18, 2010, Portland, Oregon}

\begin{tabular}{|c|c|c|}
\hline Name & Expertise & Affiliation \\
\hline James Peterson $^{1}$ & Occupancy modeling & $\begin{array}{l}\text { U.S. Geological Survey, Oregon Cooperative } \\
\text { Fisheries Research Unit }\end{array}$ \\
\hline Michael Adams & Occupancy modeling & $\begin{array}{l}\text { U.S. Geological Survey, Forest and Rangeland } \\
\text { Ecosystem Science Center }\end{array}$ \\
\hline Douglas Peterson & Demography & $\begin{array}{l}\text { U.S. Fish and Wildlife Service, Ecosystem } \\
\text { Services }\end{array}$ \\
\hline Benjamin Letcher ${ }^{2,3}$ & Demography & U.S. Geological Survey, Leetown Science Center \\
\hline Theodore Castro-Santos ${ }^{4}$ & Individual movement & U.S. Geological Survey, Leetown Science Center \\
\hline Keith Nislow $^{4}$ & Individual movement & U.S. Forest Service, Northeast Research Station \\
\hline Deborah Finn & Molecular markers & Oregon State University, Department of Zoology \\
\hline Winsor Lowe & Demography & $\begin{array}{l}\text { University of Montana, Division of Biological } \\
\text { Sciences }\end{array}$ \\
\hline Helen Neville $^{5}$ & Molecular Markers & Trout Unlimited \\
\hline Brett Albanese & Individual movement & State of Georgia Department of Natural Resources \\
\hline Mark Hudy & Individual movement & U..S Forest Service, Fisheries, Washington Office \\
\hline Jason Dunham & Workshop organizer & $\begin{array}{l}\text { U.S. Geological Survey, Forest and Rangeland } \\
\text { Ecosystem Science Center }\end{array}$ \\
\hline Robert Hoffman & Workshop organizer & $\begin{array}{l}\text { U.S. Geological Survey, Forest and Rangeland } \\
\text { Ecosystem Science Center }\end{array}$ \\
\hline Bruce Hansen & Workshop organizer & $\begin{array}{l}\text { U.S. Forest Service, Pacific Northwest Research } \\
\text { Station }\end{array}$ \\
\hline Guillermo Giannico & Workshop organizer & $\begin{array}{l}\text { Oregon State University, Department of Fisheries } \\
\text { and Wildlife and OSU Extension }\end{array}$ \\
\hline Kim Clarkin & Workshop organizer & $\begin{array}{l}\text { U.S. Forest Service, San Dimas Technology and } \\
\text { Development Center }\end{array}$ \\
\hline
\end{tabular}

${ }^{1}$ Occupancy Presentation: http://www.fsl.orst.edu/geowater/PEP/aopw/peterson

${ }^{2}$ Demography Presentation: $\underline{\text { http://www.fsl.orst.edu/geowater/PEP/aopw/letcher-demography }}$

${ }^{3}$ Molecular Markers-Sibship Presentation: http://www.fsl.orst.edu/geowater/PEP/aopw/letcher-sibship

${ }^{4}$ Individual Movement Presentation: http://www.fsl.orst.edu/geowater/PEP/aopw/castro-santos

${ }^{5}$ Molecular Markers Presentation: http://www.fsl.orst.edu/geowater/PEP/aopw/neville 
Publishing support provided by the U.S. Geological Survey Publishing Network, Tacoma Publishing Service Center

For more information concerning the research in this report, contact the Director, Forest and Rangeland Ecosystem Science Center

U.S. Geological Survey

777 NW 9th Street, Suite 400

Corvallis, Oregon, 97330

http://fresc.usgs.gov/ 
